\title{
LIMITED LIABILITY AND THE KNOWN UNKNOWN
}

\author{
MICHAEL SIMKOVIC $\dagger$
}

\begin{abstract}
Limited liability is a double-edged sword. On the one hand, limited liability may help overcome investors' risk aversion and facilitate capital formation and economic growth. On the other hand, limited liability is widely believed to contribute to excessive risk-taking and externalization of losses to the public. The externalization problem can be mitigated imperfectly through existing mechanisms such as regulation, mandatory insurance, and minimum capital requirements. These mechanisms would be more effective if information asymmetries between industry and policymakers were reduced. Private businesses typically have better information about industry-specific risks than policymakers.
\end{abstract}

A charge for limited liability entities - resembling a corporate income tax but calibrated to risk levels-could have two salutary effects. First, a well-calibrated limited liability tax could help compensate the public fisc for risks and reduce externalization. Second, a limited liability tax could force private industry actors to reveal information to policymakers and regulators, thereby dynamically improving the public response to externalization risk.

Charging firms for limited liability at initially similar rates will lead relatively low-risk firms to forgo limited liability, while relatively highrisk firms will pay for limited liability. Policymakers will then be able to focus on the industries whose firms have self-identified as high risk, and thus develop more finely tailored regulatory responses. Because the benefits of making the proper election are fully internalized by individual firms, whereas the costs of future regulation or limited liability

Copyright (C 2018 Michael Simkovic.

$\dagger$ Professor of Law \& Accounting, USC Gould School of Law. Thanks to Scott Altman, Reuven Avi-Yonah, Lily Batchelder, Jeffrey Colon, Mirit Eyal-Cohen, Victor Fleischer, Brian Galle, Martin Gelter, Michael Guttentag, Sean Griffith, Gillian Hadfield, Henry Hansmann, Robert Hockett, Calvin Johnson, Mitchell Kane, Edward Kleinbard, Dan Klerman, Adam Levitin, Saul Levmore, Lynn LoPucki, Omri Marian, Geoffrey Miller, John Morley, Saule Omarova, James Park, Frank Partnoy, Elizabeth Pollman, Robert Rasmussen, Sarath Sanga, Dan Shaviro, Linda Sugin, Richard Squire, and Alex Raskolnikov for helpful comments and suggestions. Thanks to Sally Yi, Claudia Lin, Courtney DeKlotz, and Kai-Jen Chen for research assistance. 
tax changes will be borne collectively by industries, firms will be unlikely to strategically mislead policymakers in electing limited or unlimited liability. By helping to reveal private information and focus regulators' attention, a limited liability tax could accelerate the pace at which policymakers learn, and therefore, the pace at which regulations improve.

\section{TABLE OF CONTENTS}

Introduction: The Life Cycle of Risk and Limited Liability ..............277

I. An Overview of Limited Liability ....................................................283

A. Limited liability as mispriced insurance ………….............228

II. How Limited Liability Can Exacerbate Externalization..............289

A. Asymmetric payoffs and limited assets at risk ...................290

1. Increasing variability of outcomes ...................................291

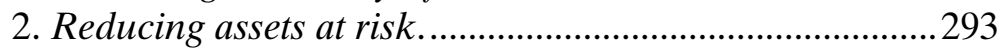

B. Risk aversion and diversification ......................................293

C. Shareholder-centric corporate governance ........................296

D. Multiple periods, dividends, interest, and salaries ............298

E. Beyond shareholders: creditors and counterparties.........299

F. How big of a problem? .......................................................304

III. Previous Solutions and their Limitations.......................................306

A. Unlimited liability is limited by collection challenges .....307

B. Safety regulation is limited by regulators' knowledge of

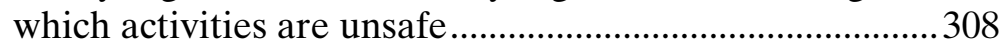

C. Minimum asset requirements reduce competition ............309

D. Insurance requires measurable risk and policing

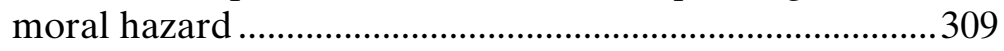

IV. A Proposed Solution: Limited Liability as an Information-

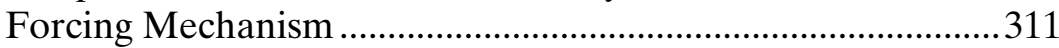

A. Dynamic, iterative pricing of the unknown........................312

B. Choosing a tax base to scale firms .......................................318

1. The greater of revenue or expenditures............................318

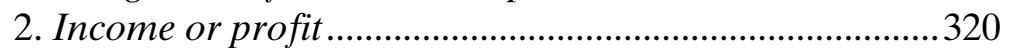

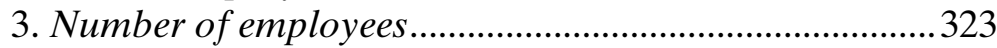

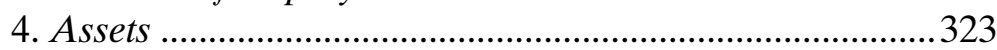

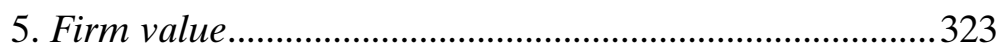

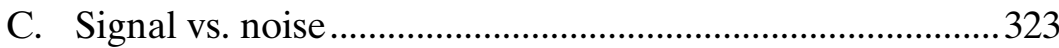

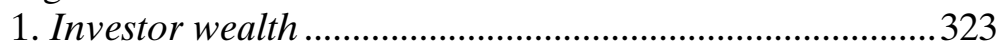

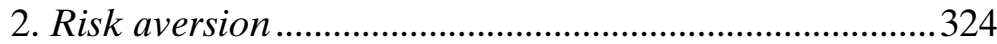

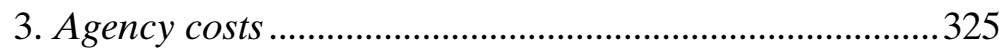

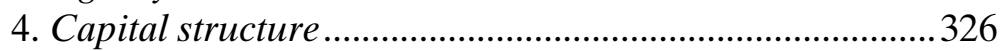




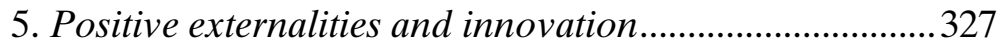

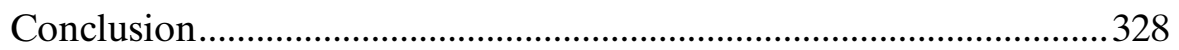

Appendix: Administrative Details .......................................................329

A. Multi-tier companies and pyramiding...................................329

B. Who should collect?...............................................................330

C. How should the money be spent? .......................................330

\section{INTRODUCTION: THE LIFE CYCLE OF RISK AND LIMITED LIABILITY}

The last two centuries have brought remarkable progress in global wealth and health. Since the early 1800s, real GDP per capita has increased more than fivefold, ${ }^{1}$ while global life expectancy has more than doubled. ${ }^{2}$ Improvements in life expectancy and quality of life, while facilitated by rising levels of productivity and prosperity, appear to be due in large part to the growth of scientific knowledge and its application to personal and public health. ${ }^{3}$

Business investment is an important driver of economic growth and innovation. However, economic activity can entail substantial risks to life and property, not only for investors, but for the broader public. These risks are often unknown or, at best, incompletely understood. Well-documented estimates suggest that currently known negative externalities could be in the range of 5 to 20 percent of GDP per year. ${ }^{4}$

Investors are skittish about accepting potentially unlimited liability for risks they only partially understand. Investors and business promoters have therefore lobbied for and been granted easy access to limited liability. ${ }^{5}$ Limited liability prevents investors from losing more than the capital that they invest in a business. As profits accumulate (or the business winds down), investors can liberate capital from the hazardous confines of an operating company and provide it with a safer perch. ${ }^{6}$

1. Jutta Bolt \& Jan Luiten van Zanden, The Maddison Project: Collaborative Research on Historical National Accounts, 67 ECON. HIST. REV. 627, 637 (2014).

2. See James C. Riley, Rising Life Expectancy: A Global History 1 (2001); James C. Riley, Estimates of Regional and Global Life Expectancy, 1800-2001, 31 POPULATION \& DEV. REV. 537, 542 (2005).

3. David Cutler, Angus Deaton \& Adriana Lleras-Muney, The Determinants of Mortality, 20 J. ECON. PERSP. 97, 116-17 (2006).

4. See infra notes 113-28 and accompanying text.

5. See Susan Pace Hamill, The Limited Liability Company: A Catalyst Exposing the Corporate Integration Question, 95 MICH. L. REV. 393, 399-400 (1996).

6. See infra Part II.D. 
Limited liability for torts and similar involuntary claims is a double-edged sword. On the one hand, limited liability may help overcome investors' risk aversion and facilitate investment and economic growth. On the other hand, limited liability is generally believed to contribute to excessive risk-taking and externalization of losses to the public. ${ }^{7}$ Limited liability cannot eliminate risk. It can only transfer the adverse consequences of risk away from the actor who is effectively deciding how much risk to take and, in so doing, encourage greater risk-taking. Limited liability in contract is uncontroversial because it is a default rule that can be altered by agreement. ${ }^{8}$

Over time, a given risk that was once unknown will become increasingly familiar, identifiable, measurable, predictable, and ultimately possible to regulate or insure against. ${ }^{9}$ Unknown risks often have a life cycle. In the early stages, risks begin to reveal themselves to those most intimately familiar with an activity. Near misses proliferate and relatively small private losses accumulate, but the magnitude of any loss externalization is too small to capture the attention of the public or policymakers. ${ }^{10}$ Private businesses and their sophisticated investors typically have better information about industry-specific risks than policymakers. Private market actors who are most attuned to these risks may move to insulate themselves and externalize the risk onto others who are less knowledgeable. ${ }^{11}$ Over time, as economic activity

7. Henry Hansmann \& Reinier Kraakman, Toward Unlimited Shareholder Liability for Corporate Torts, 100 YALE L.J. 1879, 1879 (1991).

8. Henry Hansmann \& Reinier Kraakman, A Procedural Focus on Unlimited Shareholder Liability, 106 HARV. L. REV. 446, 451 (1992); Robert J. Rhee, Bonding Limited Liability, 51 WM. \& MARY L. REV. 1417, 1421, 1425 (2010). Liability to contractual counterparties can be further limited through asset partitioning and contractual non-recourse provisions. Limited liability can be waived through guarantees. In a Coasian world without transaction or bargaining costs, changing the default rule with respect to limited liability in contract would have no effect. R. H. Coase, The Problem of Social Cost, 3 J.L. \& ECON. 1, 6 (1960).

9. Cf. generally Michelle E. Boardman, Known Unknowns: The Illusion of Terrorism Insurance, 93 GEO. L.J. 783 (2005) (emphasizing, in the context of terrorism insurance, the role of risk measurement to insuring risks).

10. See generally Anthony J. Casey \& Eric A. Posner, A Framework for Bailout Regulation, 91 Notre DAME L. REV. 479, 495-522 (2015) (describing financial services, manufacturing, and transportation bailouts).

11. Cf., e.g., Saul Levmore, Coalitions and Quakes: Disaster Relief and Its Prevention, 3 U. CHI. L. SCH. ROUNDTABLE 1, 7 (1996) ("[F]lood relief or subsidized flood insurance may encourage inefficient building on flood plains.”); Jeffrey Manns, Building Better Bailouts: The Case for a Long-Term Investment Approach, 63 FLA. L. REV. 1349, 1368 (2011) (noting that pursuing the insurance and stabilization goals of government bailouts "may magnify moral hazards and dangers of overuse or abuse by government and corporate beneficiaries, who may seek to engage in greater risk-taking at the public's expense"); Steven L. Schwarcz, Systemic Risk, 97 GEO. L.J. 193, 
increases and the cumulative probability of negative outcomes rises, externalized losses grow.

Today we take it for granted that industrial pollution is a health hazard. Many air pollutants cause severe and costly respiratory and cardiovascular problems for individuals who neither earn their livelihoods producing industrial goods nor make use of the responsible products. ${ }^{12}$ Pollution is the classic example of an externality. ${ }^{13}$ Although industrialization began in Britain in the late eighteenth century, links between air pollution and health only began to be researched in the United States in the 1950s, after particularly severe incidents of pollution in the 1940s and 1950s commanded attention. ${ }^{14}$ Air pollution was not regulated at the federal level until the 1970s. ${ }^{15}$ Recent research continues to identify new links between health problems and manmade sources of pollution. ${ }^{16}$

It is likely that individuals directly involved in industry, with greater exposure and greater expertise, would have been cognizant of health risks earlier than the public or policymakers. For example, many tobacco company scientists believed that smoking was harmful to health as early as the $1950 \mathrm{~s} .{ }^{17}$ Yet as late as 1999 , the tobacco industry publicly maintained that there was no scientific proof that tobacco causes health problems. ${ }^{18}$

210-11, 225 n.202 (2008) (noting that federal insurance funded by taxpayers encourages bank risktaking).

12. Ralph Estes, TyRanNy OF THE BotTom Line: Why Corporations MaKe GOOD PEOPLe Do BAD THINGS 185-89 (1996).

13. William J. Baumol, On Taxation and the Control of Externalities, 62 Am. ECON. REV. 307, 307 (1972).

14. Alvin Powell, Air Pollution's Invisible Toll, HARv. UnIv. CTR. FOR ENV'T (June 9, 2014), http://environment.harvard.edu/news/huce-headlines/air-pollutions-invisible-toll [https:// perma.cc/EE9S-KK5V]; History of Air Pollution, U.S. EnVTl. Protection AgenCY, https:// www.epa.gov/air-research/history-air-pollution [https://perma.cc/6GUH-6QZ9].

15. Powell, supra note 14; U.S. ENVTL. ProteCtion AgENCY, supra note 14.

16. See Michael S. Friedman, Kenneth E. Powell, Lori Hutwagner, LeRoy M. Graham \& W. Gerald Teague, Impact of Changes in Transportation and Commuting Behaviors During the 1996 Summer Olympic Games in Atlanta on Air Quality and Childhood Asthma, 285 JAMA 897, 897 (2001); Chris A. McLinden et al., Space-Based Detection of Missing Sulfur Dioxide Sources of Global Air Pollution, 9 NAture Geoscience 496, 496 (2016).

17. K. M. Cummings, C. P. Morley \& A. Hyland, Failed Promises of the Cigarette Industry and Its Effect on Consumer Misperceptions About the Health Risks of Smoking, 11 TOBACCO CONTROL i110, i111 (2002).

18. See NaOmi Oreskes \& ERIK M. CONWAy, Merchants of DoubT: How a Handful of SCIENTISTS ObSCURED THE TRUTH ON ISSUES FROM TOBACCO SMOKE TO GlobaL WARMING 10-35 (2011); Cummings et al., supra note 17, at i110; Jon D. Hanson \& Kyle D. Logue, The Costs of Cigarettes: The Economic Case for Ex Post Incentive-Based Regulation, 107 YALE 
If losses grow large enough, they will capture the attention of the public and of policymakers, and may lead to post hoc bailouts or relief efforts. ${ }^{19}$ Even without an identifiable bailout, externalized costs may burden social programs that insure against poor health, disability, or poverty, or programs that provide for public safety. ${ }^{20}$ The social costs of relief efforts eventually create pressure to regulate the activity in order to reduce risks, or to introduce a formalized system of mandatory insurance in which industry participants (or vulnerable groups) pay, at least in part, for the relief that they are likely to eventually receive. ${ }^{21}$ Formal insurance schemes become more tenable as risks become more clearly identified, measurable, and actuarially predictable..$^{22}$

This life cycle model roughly describes the evolution of bailouts, regulation, and compulsory insurance schemes in many different industries and at various points in U.S. history. ${ }^{23}$ What should be noted is that during the early stages of the cycle, when risks are poorly understood by most, limited liability provides investors with insurance-like benefits without the expense of insurance premiums or the restraint and cost of safety regulations. ${ }^{24}$

The long history of iterative discovery of risk suggests several insights. First, there are risks that are largely unknown and unknowable to most parties. Second, the best information about these risks, albeit potentially very limited, is likely in the hands of industry participants.

L.J. 1163, 1171-72 (1998).

19. See DAVID SKEel, THE NEW FinANCIAL DEAL: Understanding THE DodD-Frank ACt AND Its (Unintended) ConseQuences 132-35 (2010); Adam J. Levitin, In Defense of Bailouts, 99 GEO. L.J. 435, 438-39 (2011); Levmore, supra note 11, at 15, 17; Manns, supra note 11, at 1361; Jeffrey Manns, Insuring Against Terror?, 112 YALE L.J. 2509, 2526 (2003).

20. See Levmore, supra note 11, at 5, 9-12, 31 (discussing unemployment and health insurance).

21. See id. at 12; Manns, supra note 11 , at 1381.

22. See infra note 143 and accompanying text.

23. See Fed. Deposit Ins. Corp., A Brief History of Deposit Insurance in the UNITED STATES, 3-4, 7, 17-27 (1998), https://www.fdic.gov/bank/historical/brief/brhist.pdf [https://perma.cc/53V9-4YE6]; Eugene A. Rosa \& William R. Freudenburg, The Historical Development of Public Reactions to Nuclear Power, in Public Reactions to NuClear Waste 32, 32-34 (Riley E. Dunlap, Michael E. Kraft \& Eugene A. Rosa eds., 1993) (describing the gradual growth of public awareness of the risks of nuclear power and the resulting development of safety regulations and public insurance); Levmore, supra note 11, at 1-2, 12 (describing the development of federal flood insurance).

24. See Hansmann \& Kraakman, supra note 7, at 1929. When crises reveal the magnitude of risk, the public's reaction could lead to overregulation. See Brett McDonnell, Dampening Financial Regulatory Cycles, 65 FLA. L. REV. 1597, 1599 (2013); Roberta Romano, Regulating in the Dark 1 (Yale Prog. for Stud. in Law, Econ., \& Pub. Policy Research Paper Series, Research Paper No. 442, 2012), https://ssrn.com/abstract=1974148 [https://perma.cc/C6CV-KXN2]. 
Third, limited liability, dividends, interest payments, and other judgment-proofing strategies enable investors and industry participants to benefit from gains while externalizing losses onto third parties (particularly where limited liability does not correct existing risk aversion or agency costs). Fourth, holding the costs of these strategies constant, externalization strategies will most often be used where the benefits are greatest - that is, where there is the greatest opportunity to externalize losses that would otherwise have been borne by investors.

The fact that these risks are not known and are not precisely quantifiable does not mean that nothing should be done to address them. One can safely assume that the costs of externalized risks-and the commensurate benefits to investors and employees - are greater than zero. Thus, even a modest countervailing policy would be an improvement over the status quo. ${ }^{25}$

A contemporaneous charge for limited liability and entities that shield assets from involuntary claimants-loosely modeled on the corporate income tax but more closely calibrated to risk levels - might offer a promising solution. Despite the inevitable challenges of accurately measuring risk levels ex ante and of enforcing unlimited liability ex post, a limited liability charge would be a powerful policy tool.

Indeed, simply introducing such a charge will dynamically improve regulators' and policymakers' ability to price and police unknown risks. This is because industry participants' choices to pay the proposed fee or forgo protection will reveal information to regulators and policymakers about knowledgeable parties' internal assessments of risk.

When limited liability comes at a cost, those who believe that they are engaged in riskier activities will be more likely to opt into limited liability, while those who believe their actions are comparatively benign will be more likely to forgo it. ${ }^{26}$ If limited liability were priced uniformly relative to scale, then variation in the proportion of similar firms that opt into limited liability would reveal information about private

25. See Glenn Shafer, A Mathematical Theory of EVIDENCE 250-51 (1976) (discussing Bayesian priors); Hansmann \& Kraakman, supra note 7, at 1883.

26. Ian Ayres and Robert Gertner have noted the advantages of penalty defaults as a mechanism to force informed parties to share information with counterparties by attempting to contract around the default rule. Ian Ayres \& Robert Gertner, Filling Gaps in Incomplete Contracts. An Economic Theory of Default Rules, 99 YALE L.J. 87, 98-100 (1989).

Alex Raskolnikov has similarly proposed to use tax elections to force taxpayers to self-sort and reveal information about their propensity for tax evasion. Alex Raskolnikov, Revealing Choices: Using Taxpayer Choice to Target Tax Enforcement, 109 COLUM. L. REV. 689, 691 (2009). 
assessments of the relative riskiness of various activities. Although risks are assumed to be nearly uniform within a group, information about risk and perceptions of risks still vary among members of the group. ${ }^{27}$ Thus, elections regarding limited liability would aggregate and reveal information about risk, much as market pricing or prediction markets aggregate and reveal information. ${ }^{28}$ Regulators could use this information to more closely study and eventually regulate or insure against high-risk activities.

Regulators could also iteratively reprice limited liability in subsequent periods, charging different prices to different risk-pooled groups of firms based on information revealed in the previous period. ${ }^{29}$ Thus, a risk-uniform group in which relatively few or no firms opted into limited liability in the previous period - thereby indicating relatively low risk for the group - would signal policymakers to reduce the price of limited liability in the next period. On the other hand, a risk-uniform group in which a very large proportion of firms opted into limited liability - thereby indicating relatively high risk - would signal policymakers to increase the price of limited liability in subsequent periods. Because the benefits of making the proper election are fully internalized by individual firms, whereas the costs of future regulation or limited liability tax changes will be borne collectively by the risk-uniform group (i.e., competitors within an industry), firms will be unlikely to strategically mislead policymakers when electing limited or unlimited liability. ${ }^{30}$

When prices are set such that similar firms are roughly equally likely to choose limited liability or forgo it, one can infer that the cost

27. In other words, risks are uniformly distributed within each group, but perceptions of risk are not uniformly distributed. A simplifying assumption is that such information is normally distributed.

28. Ronald J. Gilson \& Reinier H. Kraakman, The Mechanisms of Market Efficiency, 70 VA. L. REV. 549, 585 (1984); Sanford Grossman, On the Efficiency of Competitive Stock Markets Where Trades Have Diverse Information, 31 J. FIN. 573, 574 (1976); Justin Wolfers \& Eric Zitzewitz, Prediction Markets, 18 J. ECON. PERsP. 107, 112 (2004).

29. Cf. Mitchell A. Kane, Taxation and Multi-Period Global Cap and Trade, 19 N.Y.U. ENVTL. L.J. 87, 95 (2011) (discussing a multiperiod, multijurisdictional cap-and-trade system).

30. If electing for limiting liability subjects a firm to specifically and individually targeted regulatory scrutiny, a risky firm might choose unlimited liability to avoid unwanted regulatory attention. This is especially true because in practice, even with de jure unlimited liability, the firm does not fully internalize the risk. See supra note 11 and accompanying text. However, if scrutiny is spread across a group of similarly risky competing firms, collective action problems will encourage firms to make elections driven by individual risk assessments, not what is strategically advantageous for the industry as a whole. See infra Part IV. A. 
of limited liability is priced roughly at its value. ${ }^{31}$ Once limited liability is correctly priced within each category of firms, differences in the price of limited liability among different categories of firms would be a good indicator of differences in residual risk that are known or suspected by industry participants, but unknown to regulators or the public.

Regulators may be able to group firms into risk pools only imperfectly; firms within a group will inevitably be less than perfectly uniform. However, this can also be an information-forcing mechanism that could lead to dynamic improvements over time. Low-risk firms that are mistakenly grouped with high-risk firms have incentives to reveal industry-specific information that can help regulators and policymakers better distinguish between high-risk and low-risk firms.

Costly, rather than costless, limited liability could thereby pressure industry to share information with the public through limited liability election. By helping to reveal private information and focus regulators' attention, a limited liability tax could accelerate the pace at which policymakers learn, and therefore, the pace at which regulations improve.

Part I of this Article provides an overview of limited liability, discussing the reasons for limited liability and conceptualizing it as a form of insurance. Part II describes problems with limited liability, such as how it can facilitate externalization. It includes estimates of how large the externalization problem might be. Part III describes previous solutions to the externalization problem and their limitations. Part IV presents a novel approach to charging for limited liability and iteratively pricing it to force firms to reveal information about internal assessments of risks to the public. After the conclusion, Part IV is followed by an Appendix, which discusses some administrative details.

\section{AN OVERVIEW OF LIMITED LIABILITY}

Liability is limited in practice without the law making it so. Individuals and firms are often capable of producing harm that exceeds their capacity to compensate victims because both their assets and their future earning capacity are limited. This is known as the "judgmentproof problem." ${ }^{32}$ Liability can be further limited by operation of law.

31. If one assumes some risk aversion, then the optimal price may be one at which more than half of firms choose limited liability, though not all. If all firms choose limited liability, that would be a clear sign that limited liability is underpriced.

32. Steven Shavell, Liability for Harm Versus Regulation of Safety, 13 J. LEGAL STUD. 357, 360-61 (1984) [hereinafter Shavell, Liability for Harm]; Steven Shavell, A Model of the Optimal 
"Limited liability" commonly refers to legal protections that prevent claimants who are harmed by a firm from collecting against the firm's investors when the assets of the firm are not sufficient to cover claims against the firm. Firms can therefore remove assets from the reach of claimants by distributing assets to investors.

Scholarship addressing the judgment-proof problem and related issues has focused on losses imposed on nonadjusting or involuntary creditors, like the government or tort victims. In contrast, sophisticated financial investors such as bank lenders are believed to protect themselves from risk through negotiated lending terms such as interest rates, security, and covenants. ${ }^{33}$ Although sophisticated creditors can obtain priority and maximize recovery for themselves in the event of losses or demand high interest rates to compensate themselves for risk, unsophisticated creditors who typically lack such protections cannot free ride on sophisticated creditors' efforts.

Judgment proofing can lead to overinvestment in risky activities, underinvestment in safety precautions, and underinsurance. ${ }^{34}$ In other words, the judgment-proof problem is not simply a question of distribution -it also raises efficiency concerns.

The law limits liability even further. State property-exemption laws and the federal bankruptcy code shield many individual assetsand in the case of bankruptcy, much of future income-from the reach of most creditors. ${ }^{35}$ State business-entity laws provide limited liability

Use of Liability and Safety Regulation, 15 RAND J. ECON. 271, 271 (1984).

33. See Lucian Arye Bebchuk \& Jesse M. Fried, The Uneasy Case for the Priority of Secured Claims in Bankruptcy, 105 YALE L.J. 857, 882 (1996); Victor Brudney, Corporate Bondholders and Debtor Opportunism: In Bad Times and Good, 105 HARV. L. REV. 1821, 1821 (1992); Yair Listokin, Is Secured Debt Used to Redistribute Value from Tort Claimants in Bankruptcy? An Empirical Analysis, 57 DUKE L.J. 1037, 1051 (2008).

34. Hansmann \& Kraakman, supra note 7, at 1882-83 (1991); Lynn M. LoPucki, The Death of Liability, 106 YALE L.J. 1, 20-22 (1996).

This assumes the background legal liability regime either appropriately deters or underdeters excessive risk-taking when judgments are fully collectible. In other words, [expected liability] $\leq$ [expected harm]. Shavell argues that setting liability equal to harm in individual cases could under-deter because there is some probability that in cases in which harm is done, tortfeasors will not be identified, suit will not be brought, or plaintiffs will not prevail. Shavell, Liability for Harm, supra note 32, at 363-70. Many kinds of harm are not actionable, for example, because of statutory immunity. See, e.g., The Protection of Lawful Commerce in Arms Act, Pub. L. 109-92, 119 Stat. 2095 (2005) (codified as 15 U.S.C. $\$ \S 7901-03$ (2012)) (banning lawsuits against gun manufacturers and distributors when their products are used to commit crimes). Those who believe that tort liability is excessive may view limited liability and asset protection as backdoor corrective reforms. Hansmann \& Kraakman, supra note 7, at 1918.

35. Thomas H. Jackson, The Fresh-Start Policy in Bankruptcy Law, 98 HARV. L. REV. 1393, 1393 (1985) (explaining the bankruptcy discharge and property exemptions as providing a "fresh 
for investors in corporations and other entities. Legislators created these limits on liability to help overcome individual risk aversion, facilitate transferability of equity ownership and reduce search costs, and facilitate socially beneficial investments. ${ }^{36}$

Stephen Bainbridge and M. Todd Henderson trace the historical origins of limited liability to sovereign immunity.${ }^{37}$ Early corporations were granted exclusive authority to perform functions that had traditionally been performed by the state, and therefore they enjoyed statelike protection from creditors..$^{38}$ According to Bainbridge, Henderson, and Stephen B. Presser, broad-based limited liability became widely available to small businesses in the United States because of the decentralization of corporate law, competition between states for charters and investment, and political pressure from business leaders and their lawyers. ${ }^{39}$

Bainbridge and Henderson applaud this development. They view limited liability as helpful, and perhaps even essential, to capital formation and economic growth. ${ }^{40}$ Limited liability helps overcome investors' risk aversion in a world in which businesses' vast needs for capital and professional expertise necessitate the separation of ownership and control. Limited liability also eliminates the complexity and illiquidity that could result if an individual investor's personal liability turned on the personal wealth of other investors or the particular time when frequently traded investments were owned.$^{41}$ And while shareholders and many voluntary creditors could contract for limited liability, a default rule establishing limited liability (unless specifically waived) saves them the time and expense.

start" and preventing debt overhang).

36. For an overview of justifications for limited liability, see STEPHEN M. BAINBRIDGE \& M. Todd Henderson, Limited Liability ch. 3 (2016). See also Paul Halpern, Michael Trebilcock \& Stuart Turnbull, An Economic Analysis of Limited Liability in Corporation Law, 30 U. TORONTO L.J. 117, 118-26 (1980) (discussing similar legislative motivations behind limited liability laws in England and Canada).

37. BAINBRIDGE \& HENDERSON, supra note 36, at 20-32.

38. Robert C. Hockett \& Saule T. Omarova, "Special," Vestigial, or Visionary? What Bank Regulation Tells Us About the Corporation-and Vice Versa, 39 SEATTLE U. L. REV. 453, 463-69 (2016).

39. BAINBRIDGE \& HENDERSON, supra note 36, at 32-38, 52-53, 77 \& n.112, 230; see also generally STEPHEN PRESSER, PIERCING THE CORPORATE VEIL 19-24 (2018) (discussing the history of limited liability in U.S. states).

40. BAINBRIDGE \& HENDERSON, supra note 36 at 19, 302.

41. Id. at $11-12,54-66,82-83$. 
The prospect of imposing unlimited liability on contractual counterparties and creditors in the general course would be a radical departure from established practice. ${ }^{42}$ Although lender liability might improve efficiency in some contexts ${ }^{43}$ most advocates of unlimited shareholder liability have shied away from lender and contractual counterparty liability except in extraordinary circumstances because such liability could exacerbate conflict within the capital structure and create information problems. ${ }^{44}$ Unlimited liability for investors makes the value of the investment to each investor dependent on the wealth of other investors who can satisfy judgments if liability is joint and several. ${ }^{45}$ It also raises complicated problems about the timing of ownership of a stake in a firm and when liability should attach ${ }^{46}$ which could dramatically restrict liquidity. ${ }^{47}$

Even when liability is not limited by law, it may be limited in fact by the high costs of collecting small sums from many investors. Such practical considerations influence doctrine. For example, suppose that payouts to a firm's shareholders or bondholders following a leveraged buyout leave that firm undercapitalized. Although fraudulent transfer law and nationally uniform procedures in bankruptcy theoretically could be used to recover the payouts, courts have broadly construed a variety of legal defenses that make such remedies particularly unlikely against small investors. ${ }^{48}$ In the modern era, with more sophisticated techniques of judgment proofing and financial engineering widely available, retroactive recoveries might be substantially lower and costs

42. Lenders and contractual counterparties may face liability-beyond the loss of their investment - in very limited contexts related to the cleanup of hazardous waste under the Comprehensive Environmental Response, Compensation, and Liability Act (CERCLA) and related legislation. Rohan Pitchford, How Liable Should a Lender Be? The Case of Judgment-Proof Firms and Environmental Risk, 85 AM. ECON. REV. 1171, 1181-82 (1995).

43. Id.

44. Hansmann \& Kraakman, supra note 7, at 1930; David W. Leebron, Limited Liability, Tort Victims, and Creditors, 91 ColuM. L. REV. 1565, 1641-43 (1991); Alan O. Sykes, The Economics of Vicarious Liability, 93 YALE L.J. 1231, 1253 (1984).

45. Hansmann \& Kraakman, supra note 7, at 1906; Halpern, Trebilcock \& Turnbull, supra note 36 , at $129-31$.

46. For a proposed solution, see infra note 111 .

47. Janet Cooper Alexander, Unlimited Shareholder Liability through a Procedural Lens, 106 HARV. L. REV. 387, 391 \& n.15 (1992).

48. See Michael Simkovic \& Benjamin S. Kaminetzky, Leveraged Buyout Bankruptcies, the Problem of Hindsight Bias, and the Credit Default Swap Solution, 2011 CoLuM. BuS. L. REV. 118, 133-34 (2011); Michael L. Cook, Another Court of Appeals Broadly Reads Settlement Payment Safe Harbor, HARV. Blogs: BANKRUPTCY RoundTABLE (May 13, 2014), http://blogs.law.harvard.edu/bankruptcyroundtable/2014/05/13/another-court-of-appeals-broadly-reads-settlementpayment-safe-harbor [https://perma.cc/BH2N-84AH]. 
of collection substantially higher.

Empirical evidence suggests that large, capital-intensive businesses can function without limited liability for shareholders, at least in certain legal environments. ${ }^{49}$ In the late nineteenth and early twentieth centuries, double-liability regimes for shareholders of commercial banks permitted partial recoveries, though often with substantial cost and delay. ${ }^{50}$ American Express operated without limited liability until the 1960 s. $^{51}$ Many scholars argue that limited liability was less important to capital formation and economic growth than the emergence of business entities that facilitated asset partitioning. ${ }^{52}$

Nevertheless, the view that limited liability attracts investors is relatively uncontroversial. Henderson and Bainbridge, though clearly

49. See E. Merrick Dodd, The Evolution of Limited Liability in American Industry: Massachusetts, 61 HARV. L. REV. 1351, 1356 (1948); Jonathan R. Macey \& Geoffrey P. Miller, Double Liability of Bank Shareholders: History and Implications, 27 WAKE FOREST L. REV. 31, 55 (1992); Mark I. Weinstein, Don't Buy Shares Without It: Limited Liability Comes to American Express, 37 J. LEGAL STUD. 189, 194 (2008) [hereinafter Weinstein, American Express]; Mark I. Weinstein, Share Price Changes and the Arrival of Limited Liability in California, 32 J. LEGAL STUD. 1, 2-3 (2003) [hereinafter Weinstein, California].

Critics have suggested that changes in substantive and procedural law, such as the rise of mass torts and class action lawsuits, have increased potential liability dramatically. Previous periods when large businesses operated without the benefit of limited liability might therefore not predict what would happen in the current legal regime if limited liability were removed. See BAINBRIDGE \& HENDERSON, supra note 36, at 40-42, 66; Richard A. Posner, The Rights of Creditors of Affiliated Corporations, 43 U. CHI. L. REV. 499, 515 (1976). Others argue that the unprecedented abundance of financial capital makes current investors more risk tolerant. See Hockett \& Omarova, supra note 38, at 485-87.

50. See Peter Conti-Brown, Elective Shareholder Liability, 64 STAN. L. REV. 409, 436, 45859 (2012); Howell E. Jackson, Losses from National Bank Failures during the Great Depression: A Response to Professors Macey and Miller, 28 WAKE FOREST L. REV. 919, 922 (1993) (noting substantial delays and challenges of collecting from shareholders, especially during the Great Depression); Macey \& Miller, supra note 49, at 55 (finding nominal 50 percent recovery rates over time).

51. Weinstein, American Express, supra note 49.

52. Henry Hansmann \& Reinier Kraakman, The Essential Role of Organizational Law, 110 YALE L.J. 387, 390 (2000) ("[L]imited liability . . . is . . of distinctly secondary importance. The truly essential aspect of asset partitioning is . . the reverse of limited liability - namely, the shielding of the assets of the entity from claims of the creditors of the entity's owners or managers."); Henry Hansmann, Reinier Kraakman \& Richard Squire, Law and the Rise of the Firm, 119 HARV. L. REV. 1335, 1336 (2006) ("While limited liability has evident and important functional complementarities to entity shielding, it is neither necessary nor sufficient for the creation of business firms as separate and distinct economic actors. Firms can prosper without limited liability, but significant enterprises lacking entity shielding are largely unknown in modern times.”). 
strong proponents of limited liability, acknowledge that limited liability creates problems of its own-private profits can be amplified, with no social benefit, through externalization of losses onto the public. ${ }^{53}$

Henry Hansmann views limited liability for torts as a largely unnecessary and unfortunate development in corporate law. ${ }^{54}$ Hansmann acknowledges that joint and several unlimited liability might create search costs and information problems for investors, who would be concerned with the wealth of other investors in a venture and their capacity to pay judgments. ${ }^{55}$ However, Hansmann's analysis suggests that proportionate unlimited liability for torts - that is, liability proportionate to an investor's stake in the business - would not create such problems and would avoid many of the problems associated with limited liability. ${ }^{56}$ Proportionate unlimited liability for torts is therefore an alternative to limited liability. As discussed below in Part II.E., Hansmann's analysis and subsequent critiques imply that proportionate unlimited liability for torts should be extended not only to shareholders, but also to other financial investors in the firm..$^{57}$

\section{A. Limited liability as mispriced insurance}

Given the choice between proportionate unlimited liability and limited liability, most investors would prefer limited liability. Legal scholars have generally concluded that the benefits of providing limited liability usually outweigh the costs. ${ }^{58}$ But this does not necessarily mean that governments should provide limited liability for free, any more than governments should provide costly physical infrastructure without charging user fees.

Limited liability resembles insurance. Limited liability entities obtain insurance-like benefits, in that the owners of limited liability entities can offload risks of certain losses. In insolvencies of limited liability entities, some losses are borne by governments. ${ }^{59}$ Indeed, actual insolvency is unnecessary for limited liability to facilitate loss externaliza-

53. BAINBRIDGE \& HENDERSON, supra note 36, at 47-51, 225.

54. Hansmann \& Kraakman, supra note 7, at 1895.

55. Id. at $1890-91$.

56. Id. at $1893-94$.

57. Id. at 1898 .

58. See Phillip I. Blumberg, Limited Liability and Corporate Groups, 11 J. CoRP. L. 573, 61116 (1986).

59. See Steven L. Schwarcz, Too Big to Fool: Moral Hazard, Bailouts, and Corporate Responsibility, 102 MINN. L. REV. 1, 9 (2017). 
tion. The mere specter of liability pushing a firm to the brink of insolvency might persuade regulators, courts, and plaintiffs to agree to lower damages or forgo litigation altogether rather than expend resources seeking damages that would be uncollectible. ${ }^{60}$

Insurance providers routinely charge a premium for bearing the risk of loss, depending on the extent of the risk. Private insurance companies will only insure risks that are specific, limited, and quantifiable so that actuarial analysis can calculate profitable insurance pricing. Limited liability effectively provides uncapped insurance for any risk that might materialize, no matter how unpredictable or poorly understood. No private insurance company would offer insurance on these terms, at any price. The catastrophic insurance provided by limited liability, essentially gratis, is clearly underpriced when virtually all businesses that are aware of the availability of limited liability opt into it.

Limited liability, properly priced and accompanied by appropriate safety regulation, could create value, just as insurance helps create value by overcoming risk aversion, aggregating information about risk, and spreading sensible precautions.

\section{HOW LiMITED LIABILITY CAN EXACERBATE EXTERNALIZATION}

Limited liability exacerbates numerous problems related to judgment proofing. This is because limited liability prevents investors from losing more than their investment in a particular firm, which tends to be a relatively low fraction of each investor's net worth, and shields investors' personal income. Limited liability also facilities diversification, which dramatically increases the likelihood that a business strategy of externalizing harm will benefit investors, even those with relatively short time horizons and limited assets. Limited liability combined with diversification causes investors to behave as if they are

60. Relatively few potential plaintiffs sue, and damages awarded and actually collected tend to be modest. Deborah Jones Merritt \& Kathryn Ann Barry, Is the Tort System in Crisis? New Empirical Evidence, 60 OHIO ST. L.J. 315, 315 (1999). Deep-pocketed institutions are targeted more often than individuals with questionable ability to pay. Stephen G. Gilles, The JudgmentProof Society, 63 WASH. \& LEE L. REV. 603, 606-07 (2006). Litigation routinely settles for less than the maximum amount of defendants' insurance coverage. $C f$. David A. Hyman, Bernard Black \& Kathryn Zeiler, Do Defendants Pay What Juries Award? Post-Verdict Haircuts in Texas Medical Malpractice Cases, 1988-2003, 4 J. EMPIRICAL LEGAL STUD. 3, 56, 58 (2007) (noting that settlements in Texas medical malpractice cases are driven by expected payouts, which rarely exceed the limits of insurance coverage). 
risk neutral, because uncorrelated volatility within individual investments does not lead to high volatility in the total value of a diversified portfolio of investments.

Thanks to limited liability and diversification, a strategy of externalization can boost private returns without increasing personal financial risks. Therefore, businesses that are managed with the primary goal of maximizing shareholder value should pursue externalization strategies whenever such strategies are available. Presumably, they often do pursue such strategies.

\section{A. Asymmetric payoffs and limited assets at risk}

Parties that are judgment proof face asymmetric payoffs - unlimited upside potential and downside risk that is capped at the level of their assets and future earning capacity. Downside exceeding this cap will be externalized onto third parties and will not affect the judgmentproof party. Consider a nuclear power plant operator that could inadvertently render large portions of a city uninhabitable. If a disaster occurs, the operator will be unable to provide adequate compensation from its own assets, no matter the liability regime.

From the perspective of a profit-maximizing, judgment-proof nuclear power plant operator with $\$ 100$ million in assets, ${ }^{61}$ there is no difference between a nuclear disaster that produces $\$ 120$ million in damages ( $\$ 20$ million more than it can ever compensate) and one that produces $\$ 120$ billion in damages ( $\$ 119.9$ billion more than it can ever compensate).

Thus, skimping on maintenance in a way that will increase profitability in good times but increase the magnitude of an already catastrophic disaster - if one materializes - could maximize private benefits for the nuclear power plant operators' investors, while causing social harm. ${ }^{62}$ The dangers of nuclear power may be relatively well understood and highly regulated today, but they were not always. Consider how poorly equipped regulators are to constrain high-magnitude,

61. This example implicitly assumes that going-concern value is not substantially higher than asset value. If that is not the case, the example would still be correct as long as the amount of the judgment exceeds the greater of asset value or going-concern value.

62. See, e.g., Pat Akey \& Ian Appel, The Limits of Limited Liability: Evidence from Industrial Pollution 1, 3 (13th Annual Mid-Atlantic Research Conference in Finance (MARC) Paper, 2018), https://www.ssrn.com/abstract=3083013 [https://perma.cc/9K9J-ZUXG] (providing evidence that stronger limited liability protection for parent companies reduces investment in subsidiaries' pollution abatement technologies and increases costs borne by other stakeholders). 
low-probability risks that are not widely known or understood outside of industry until after disaster strikes.

1. Increasing variability of outcomes. Business activities have uncertain outcomes that can be understood as probability distributions, with the most likely outcomes having greater density (i.e., appearing taller on a frequency plot) and the least likely outcomestypically those that are extremely positive or negative ${ }^{63}$-having lower densities.

Holding all else constant,${ }^{64}$ the wider the probability distribution (the more extreme the outcomes) and the fatter the tails of the distribution (the more likely extreme outcomes), the more likely it is that negative outcomes will exceed the capacity to compensate victims. Because normally distributed outcomes are symmetrical, increasing the variance of the probability distribution-that is, taking on bigger risks - will increase the upside benefits for the judgment-proof party far more than the downside risks that it will face ${ }^{65}$ For example, skimping on maintenance and inspections may reduce operating costs and increase profits if all goes well, but it may also increase the likelihood and harmfulness of a disaster.

Consider a simple mathematical example. ${ }^{66}$ A particular invest-

63. Extreme outcomes are relatively unlikely when the distribution of outcomes is normal (i.e., bell shaped). Many, but not all, natural phenomena follow a normal distribution. Extreme outcomes are as likely as median or mean outcomes when the distribution is uniform (i.e., rectangular). In a few situations, the distribution may be such that extreme outcomes are more likely than moderate outcomes. The extent to which extreme outcomes are likely, relative to their likelihood under a normal distribution, is measured by kurtosis.

64. That is, holding constant assets, future earning potential, and expected returns. Expected return is the weighted average of the outcomes - that is, the sum of the probability of each outcome multiplied by its magnitude.

65. Lynn M. LoPucki, The Irrefutable Logic of Judgment Proofing: A Reply to Professor Schwarcz, 52 STAN. L. REV. 55, 61-62 (1999).

66. In mathematical notation,

$\mathrm{a}=$ investor assets and future income available for collection; $a \geq 0$

$\mathrm{f}_{\mathrm{u}}=$ likelihood of upside scenario; $0<f_{u}<1$

$\mathrm{f}_{\mathrm{d}}=$ likelihood of downside scenario; $f_{d}=1-f_{u}$

$\mathrm{m}_{\mathrm{u}}=$ magnitude of upside scenario; $m_{u}>0$

$\mathrm{m}_{\mathrm{d}}=$ magnitude of downside scenario; $m_{d}<0$

$\mathrm{V}_{\mathrm{s}}=$ expected value to society

$\mathrm{V}_{\mathrm{p}}=$ expected value to investor

$V_{s}=\left(f_{u} \cdot m_{u}\right)+\left(f_{d} \cdot m_{d}\right)$

$V_{p}=\left(f_{u} \cdot m_{u}\right)+\left(f_{d} \cdot \min \left(a,-m_{d}\right)\right)$ 
ment has an expected value of zero when all costs and benefits are internalized. The investment will only be undertaken once. There is a 90 percent chance that the investment produces $\$ 100$ million in profits. There is a 10 percent chance that the investment produces $\$ 900$ million in losses. The expected value of the more likely, profitable scenario is $\$ 90$ million while the expected value of the less likely, unprofitable scenario is negative $\$ 90$ million. The overall expected value of the investment is zero. It does not make sense for a risk-neutral investor to make this investment because there is nothing to be gained in expectation. For a risk-averse investor who fears losses more than he values gains, this investment is even less attractive.

Now introduce judgment proofing. Assume the investor has $\$ 900$ million in assets, so that he would have fully internalized the potential losses in the investment scenario described above. However, the investor takes on greater risks (i.e., increases the variance of potential outcomes) without increasing his assets. The investment now has a 90 percent chance of producing $\$ 500$ million in profits and a 10 percent chance of losing $\$ 4.5$ billion. Because both the upside and downside have quintupled, with all gains and losses fully internalized, the investment still has an expected value of zero.

However, because the judgment-proof investor can lose at most $\$ 900$ million - all of his assets - if the unprofitable scenario materializes, from the investor's perspective the expected value of the unprofitable scenario remains negative $\$ 90$ million (10 percent chance of losing $\$ 900$ million). In contrast, the expected value of the profitable scenario has increased to $\$ 450$ million, making the total expected value of the investment $\$ 360$ million to the investor and zero to society. A risk-neutral investor should now undertake this investment.

Thus,

$V_{p}=V_{s}$ if $a \geq-m_{d}$

$V_{p}>V_{s}$ if $a<-m_{d}$

The difference between the expected value to investor and the expected value to society (assuming $a<-m_{d}$ ), is

$$
\begin{aligned}
& V p-V s=f_{d} \cdot\left(-\min \left(a,-m_{d}\right)-m_{d}\right) \\
& V p-V s=f_{d} \cdot\left(\mathrm{a}+m_{d}\right)
\end{aligned}
$$

Thus, the higher the likelihood of a downside scenario exceeding the assets of the investor, and the greater the extent to which the cost of the downside scenario exceeds the assets of the investor, the larger the expected transfer from third parties to the investor. 
By changing the numbers slightly, we can also make an investment with negative value to society profitable for the investor. Thus, investors would (on average and in expectation) be able to enrich themselves by destroying value and making everyone else worse off. Companies seeking to maximize value for shareholders might actively seek to create probability distributions such that all potential losses are concentrated in scenarios in which the firm will already be insolvent, because this maximizes the chances of externalizing losses onto other parties. ${ }^{67}$

2. Reducing assets at risk. Holding all else constant, ${ }^{68}$ the lower the level of assets and future earning potential of a party, the greater the likelihood that losses will be externalized onto third parties and that judgment proofing will produce perverse incentives. This is one of the reasons that limited liability makes a strategy of externalization more effective. Limited liability can reduce the assets at risk (i.e., available to compensate victims) to the minimum amount that must remain invested in the business for the business to function.

Consider the example in section II.A. above. Suppose that the business only requires $\$ 100$ million of capital to function. With limited liability, investors can cap their losses in a downside scenario at $\$ 100$ million (the minimum assets required to run the business) rather than $\$ 900$ million (all of their assets). With limited liability, the expected value of the investment to investors increases from $\$ 360$ million to $\$ 440$ million (90\% chance of $\$ 500$ million in the upside scenario, plus $10 \%$ chance of a loss of $\$ 100$ million in the downside scenario).

This $\$ 80$ million increase in value to the investor is not value creation-it is a pure change in the distribution of value. In expectation, this value is extracted from everyone in society and transferred to the investors.

\section{B. Risk aversion and diversification}

A highly risk-averse private investor might not undertake this investment, notwithstanding the high private expected value, because

67. Lynn M. LoPucki, supra note 34, at 41-42; see Michael Simkovic \& Benjamin S. Kaminetzky, supra note 48, at 214-18. Richard Squire calls this "correlation seeking." Richard Squire, Shareholder Opportunism in a World of Risky Debt, 123 HARV. L. REV. 1151, 1152 (2010).

68. That is, holding constant the variance, mean, and other characteristics of the probability distribution. 
even the relatively low chance of losing all of his assets (or a large proportion of his assets) might deter the investor more than the prospect of gains attracts him. In other words, risk aversion helps mitigate the judgment proof problem. ${ }^{69}$

However, excessive risk aversion could also deter socially beneficial investments. Risk aversion can be mitigated through legal devices that shield assets from judgments and enable investors to undertake risky investments without the possibility of losing all of their assets and future income. These legal devices include: asset protection trusts, which shield assets placed within the trust from claims against the settlor or beneficiary of the trust $;^{70}$ state law exemptions of certain property of individuals from collections by unsecured creditors ${ }^{71}$ the Bankruptcy Code, which shields future income of individuals from collections by discharging most forms of indebtedness $;{ }^{72}$ and limited liability, which shields investors' assets-other than the investment itself-from claims against the firm. ${ }^{73}$

Limited liability may be particularly prone to exacerbate the judgment-proof problem. This is because limited liability is extremely effective at shielding investors from the consequences of failure, especially when coupled with diversification, and can therefore more completely overcome risk aversion. ${ }^{74}$

69. Steven L. Schwarcz, The Inherent Irrationality of Judgment Proofing, 52 STAN. L. REV. 1, 27-28 (1999).

70. Stewart E. Sterk, Asset Protection Trusts: Trust Law's Race to the Bottom, 85 CORNELL L. REV. 1035, 1039 (1999).

71. Richard M. Hynes, Anup Malani \& Eric A. Posner, The Political Economy of Property Exemption Laws, 47 J.L. \& ECON. 19, 19-22 (2004).

72. 11 U.S.C. $\$ \$ 523,524,727,1141,1228,1328$ (2012).

73. John Armour, Henry Hansmann, Reinier Kraakman, \& Mariana Pargendler, What is Corporate Law?, in THE ANATOMY OF CORPORATE LAW: A COMPARATIVE AND FUNCTIONAL APPROACH 9 (3d ed. 2017).

74. There is a voluminous literature in portfolio theory dedicated to calculating the optimal amount of diversification (or the ideal size of each individual investment as a share of total assets) when expected returns from each investment are positive but there is some chance of negative returns that could reduce the value of individual investments to zero but not below (i.e., liability for each investment is limited). See, e.g., Nils H. Hakansson \& William T. Ziemba, Capital Growth Theory, in 9 HANDBOOKS IN OPERATIONS RESOURCE \& MANAGEMENT SCIENCE 65, 65-86 (1995); LEONARD C. MACLEAN, EdWARD O. THORP \& W. T. ZIEMBA, THE Kelly CAPITAL Growth InVESTMENT CRITERION: THEORY AND PRACTICE 42-44, 472 (2011); Nils H. Hakansson, Capital Growth and the Mean-Variance Approach to Portfolio Selection, 6 J. FIN. \& Quantitative Analysis 517, 526 (1971); Michael Stutzer, Portfolio Choice with Endogenous Utility: A Large Deviations Approach, 116 J. ECONOMETRICs 365, 384 (2003). This literature generally suggests that risk aversion can be managed and risk of ruin minimized by increasing diversification (reducing each individual investment as a share of assets) rather than avoiding high-risk 
Personal bankruptcy and legal defenses against creditors at state law entail unpleasant, time-consuming, and potentially stigmatizing consequences for debtors, and will also typically substantially deplete their assets. Although the expected value ex ante might be $\$ 360$ million (or in the example in Part II.A.2, \$440 million), the value ex post could either be a gain of $\$ 500$ million or a loss that comes close to permanent financial ruin.

In contrast, consider an investor who diversifies by investing a relatively small portion of his assets in many different firms, each of which provides limited liability and takes risks that are uncorrelated with one another. Each investment is now like a separate roll of the dice, and thanks to limited liability, the unlimited gains and limited losses from each can be aggregated. By the law of large numbers, as the number of independent trials increases - that is, the number of uncorrelated investments in different firms increases-the ex post outcomes will increasingly approximate the ex ante expected value. ${ }^{75}$ In other words, a well-diversified investor will most likely encounter ex post outcomes that are roughly $\$ 440$ million. In practice, most investments will be at least partially correlated, so although diversification cannot completely eliminate variance, it can reduce it. ${ }^{76}$

Returning to the example of the nuclear power plant, even a riskaverse investor with small stakes in thousands of different nuclear power plants, each organized as a separate limited liability entity, and each with a chance of disaster uncorrelated with the others, should prefer that all of the nuclear plants skimp on maintenance to maximize profits in ordinary times. This, in turn, would increase the chances that losses from each plant will be externalized onto third parties.

investments with high expected value.

75. P. L. Hsu \& Herbert Robbins, Complete Convergence and the Law of Large Numbers, 33 PRoc. NAT'L. ACAD. SCI. U.S.A. 25, 25-26 (1947); Harald Uhlig, A Law of Large Numbers for Large Economies, 8 ECON. THEORY 41, 41 (1996).

76. See Harry Markowitz, Portfolio Selection, 7 J. FIN. 77, 79 (1952) ("[This] presumption[,] that the law of large numbers applies to a portfolio of securities[,] cannot be accepted. The returns from securities are too intercorrelated. Diversification cannot eliminate all variance."). 
Diversification of investments is now virtually universal. ${ }^{77}$ Costs and minimum asset requirements for diversification have largely disappeared with the growth of indexed mutual funds ${ }^{78}$ and a "duty to diversify" is now firmly established even in conservative trust law. ${ }^{79}$

\section{Shareholder-centric corporate governance}

Managers who are focused on maximizing returns to shareholders and are cognizant of limited liability and diversification should engage in risk-taking that is excessive from the perspective of social welfare. ${ }^{80}$ In contrast, agency costs-managers pursuing their own interests ahead of shareholders'-may mitigate excessive risk-taking, because risk-averse managers cannot diversify their jobs as easily as shareholders can diversify their investments. Governance innovations such as incentive compensation that align managerial interests with shareholders and encourage greater risk-taking, ${ }^{81}$ along with the general shift toward a shareholder-centric model of corporate governance, ${ }^{82}$ could exacerbate the judgment-proof problem.

Bainbridge and Henderson argue that externalization problems could be mitigated by piercing the corporate veil for shareholders who specifically direct acts that lead to liability ${ }^{83}$ But corporate tendencies toward externalization do not require shareholders or senior managers to directly control decision making. Externalization only requires that

77. See Ronald J. Gilson \& Jeffrey N. Gordon, The Agency Costs of Agency Capitalism: Activist Investors and the Revaluation of Governance Rights, 113 COLUM. L. REV. 863, 865 (2013) (explaining the triumph of the portfolio theory of investment).

78. Ajay Khorana \& Henri Servaes, What Drives Market Share in the Mutual Fund Industry?, 16 REV. FIN. 81, 97 (2012). Total market index funds that offer exposure to thousands of firmsessentially the entire U.S. stock market - are now available for annual fees as low as $0.03 \%$ of assets, and with as little as \$1 to invest. See Schwab Total Stock Market Index Fund, CHARLES SCHWAB, https://www.schwab.com/public/schwab/investing/investment_help/investment_research/mutual_fund_research/mutual_funds.html?path=\%2FProspect $\% 2$ FResearch $\% 2$ Fmutualfunds\%2Ffees.asp\%3Fsymbol\%3DSWTSX [https://perma.cc/YS9P-CBY2].

79. John H. Langbein, Questioning the Trust Law Duty of Loyalty: Sole Interest or Best Interest?, 114 YALE L.J. 929, 970 (2005).

80. William W. Bratton \& Michael L. Wachter, The Case Against Shareholder Empowerment, 158 U. PA. L. REV. 653, 658-59 (2010); Steven L. Schwarcz, Excessive Corporate Risk-Taking and the Decline of Personal Blame, 65 EMORY L.J. 533, 541-43 (2015); Squire, supra note 67, at $1201 \mathrm{n} .175$.

81. Frank H. Easterbrook, Two Agency-Cost Explanations of Dividends, 74 AM. ECON. REV. 650, 653-54 (1984); Michael C. Jensen \& William H. Meckling, Theory of the Firm: Managerial Behavior, Agency Costs and Ownership Structure, 3 J. FIN. ECON. 305, 323 (1976).

82. Henry Hansmann \& Reinier Kraakman, The End of History for Corporate Law, 89 GEO. L.J. 439, 440-41, 455 (2001).

83. BAINBRIDGE \& HENDERSON, supra note 36, at 302-04. 
managers are provided strong incentives to behave in shareholders' best interests, for example by having their compensation and job security tied to share price. Large shareholders may disproportionately invest in companies that take greater risks, generate larger short-term returns,${ }^{84}$ and pay steady dividends,${ }^{85}$ while withholding investment from companies that are managed more conservatively. Shareholders can influence executive compensation to align managerial interests more closely with their own. ${ }^{86}$ While managers correctly infer shareholders' wishes for greater risk-taking, shareholders can avoid liability for decisions that are formally made by managers. Similarly, senior managers can delegate decision making to more junior, possibly judgment-proof subordinates, reward performance that can only be

84. See Aydoğan Altı, Ron Kaniel \& Uzi Yoeli, Why Do Institutional Investors Chase Return Trends?, 21 J. FIN. INTERMEDIATION 694, 720 (2012) (concluding that institutional investors tend to "chase return trends" by buying assets with high recent returns); Geoffrey C. Friesen \& Travis R. A. Sapp, Mutual Fund Flows and Investor Returns: An Empirical Examination of Fund Investor Timing Ability, 31 J. BANKING \& FIN. 2796, 2797 (2007) (discussing studies that show that funds with better short-term performance experience greater net cash flow); Jason Karceski, ReturnsChasing Behavior, Mutual Funds, and Beta's Death, 37 J. Fin \& QUANTITATIVE AnALYsis 559, 583 (2002) (noting that mutual funds investors invest "largely on the basis of relative past performance").

85. See Easterbrook, supra note 81, at 651 (describing investors' preference for dividendpaying stocks).

86. See id. at 653-54; Patrick Bolton, Hamid Mehran \& Joel Shapiro, Executive Compensation and Risk Taking, 19 REV. FIN. 2139, 2139 (2015) ("It is well known that structuring chief executive officer (CEO) incentives to maximize shareholder value in a levered firm tends to encourage excess risk taking."); Patrick Bolton, José Scheinkman \& Wei Xiong, Executive Compensation and Short-Termist Behaviour in Speculative Markets, 73 REV. ECON. STUD. 577, 577-79 (2006); Alex Edmans \& Xavier Gabaix, The Effect of Risk on the CEO Market, 24 REV. FIN. STUD. 2822, 2822 (2011) ("A large empirical literature has shown that risk is a first-order determinant of compensation contracts."); Jensen \& Meckling, supra note 81; Richard A. Posner, Are American CEOs Overpaid, and, if so, What if Anything Should be Done About It?, 58 DUKE L.J. 1013, 1020-25 (2009); Frederick Tung, Pay for Banker Performance: Structuring Executive Compensation for Risk Regulation, 105 NW. U. L. REV. 1205, 1206 (2011); cf. Shawn Cole, Martin Kanz \& Leora Klapper, Incentivizing Calculated Risk-Taking: Evidence from an Experiment with Commercial Bank Loan Officers, 70 J. FIN. 537, 542 (2015) (summarizing how lenders use "performance pay to align the risk and time preferences of the bank's employees with [their own]").

Indeed, Robert Jackson argues that executive compensation and alignment of managerial and investor incentives is an important driver of private equity firms' success. Robert J. Jackson Jr., Private Equity and Executive Compensation, 60 UCLA L. REV. 638, 646 (2012). Lucian Bebchuk and others have argued that senior executives at publicly traded companies can sometimes shape their own compensation to reduce alignment with shareholders, but executives might do so in ways that amplify their incentives to take risks. See Lucian A. Bebchuk, Alma Cohen \& Holger Spamann, The Wages of Failure: Executive Compensation at Bear Stearns and Lehman 2000-2008, 27 YALE J. ON REG. 257, 274-76 (2010); Kevin J. Murphy, Explaining Executive Compensation: Managerial Power Versus the Perceived Cost of Stock Options, 69 U. CHI. L. REV. 847, 848-49 (2002). 
achieved through risk externalization, and disclaim any knowledge or responsibility if problems subsequently materialize. ${ }^{87}$

The rise of diversification, shareholder empowerment, and corporate governance reforms may all help overcome risk aversion and encourage value-creating investments, but in combination with limited liability, they could also exacerbate the judgment-proof and externalization problems.

\section{Multiple periods, dividends, interest, and salaries}

In the real world, most businesses are not short-term affairs that are swiftly wound up with all gains or losses distributed to investors. Instead, businesses can persist for decades, in some cases outliving their initial investors. The accumulation of profits within a business would mitigate the advantages of externalization if such profits could be seized by claimants in the event of a subsequent disaster.

Limited liability facilitates risk externalization in part because it is possible to transfer profits and valuable assets from an entity that might face future liability to investors or employees who will be shielded from such liability. If corporations retained all profits from their activities, during good years when positive outcomes materialized, corporations would build reserves which would then be available in bad years to satisfy any liability on judgments that might arise..$^{88}$

Investors can better externalize risks while investing in long-lived business entities if there are mechanisms that enable business entities to partition good years from bad. This is similar to reducing assets and increasing the variance of outcomes. ${ }^{89}$

87. Justin Fox \& Stuart V. Jordan, Delegation and Accountability, 73 J. POL. 831, 831 (2011) ("A common critique of legislative delegation of policy authority to the bureaucracy is that it undermines politicians' accountability to voters."); William S. Laufer, Corporate Liability, Risk Shifting, and the Paradox of Compliance, 52 VAND. L. REV. 1341, 1355, 1374, 1385 (1999); cf. John C. Coffee Jr., "No Soul to Damn: No Body to Kick": An Unscandalized Inquiry into the Problem of Corporate Punishment, 79 MiCH. L. REV. 386, 418, 433, 457 (1981)'.

88. See Steven A. Bank, A Capital Lock-In Theory of the Corporate Income Tax, 94 GEO. L.J. 889, 906-07 (2006); Donald Kehl, The Origin and Early Development of American Dividend Law, 53 HARV. L. REV. 36, 41 (1939) (“[I]f limited liability was to survive, a rule against impairment of corporate capital by dividends or other repayments to stockholders was inevitable."); Schwarcz, supra note 69, at 34 (identifying dividends or other transfers of value to investors as a critical step in judgment proofing).

89. These strategies make externalization more likely. See supra Parts II.A.1-2. 
These mechanisms include dividend payments to shareholders, share repurchases, ${ }^{90}$ interest payments to creditors, and (nondeferred) compensation to employees in excess of that which would be possible without limited liability. Routine payments, made while a company is apparently solvent (though engaged in risky activities), will rarely be questioned by courts. ${ }^{91}$ Legal challenges to such payments, such as fraudulent transfer or preference claims, succeed infrequently-usually when the payments are made on the eve of insolvency or under unusual circumstances suggesting coercion, value destruction, or fraud. ${ }^{92}$

Dividends, interest, and compensation - in combination with limited liability - create a one-way valve in which the benefits of risk-taking can flow to investors and key employees while the long-term costs can be externalized onto third parties.

\section{E. Beyond shareholders: creditors and counterparties}

Many analyses of limited liability have focused on the limited liability of shareholders (equity holders). ${ }^{93}$ Equity holders do not have limited liability when the business is operated as a general partnership or sole proprietorship, but they do have limited liability protection if the business is organized as a corporation, limited liability company (LLC), limited partnership (LP), or limited liability partnership (LLP). Equity investors are also generally thought to be the risk-preferring residual claimants and owners of the company, ${ }^{94}$ and therefore the most obvious beneficiaries of loss externalization through limited liability. Therefore, classic analyses of limited liability and externaliza-

90. Stock repurchases resemble dividends in that they distribute corporate cash to shareholders. However, repurchases have different transaction costs, tax consequences, effects on executive stock options, and distributive consequences. Jesse M. Fried, Insider Signaling and Insider Trading with Repurchase Tender Offers, 67 U. CHI. L. REV. 421, 421 (2000). See generally Amedeo De Cesari, Susanne Espenlaub, Arif Khurshed \& Michael Simkovic, The Effects of Ownership and Stock Liquidity on the Timing of Repurchase Transactions, 18 J. CORP. FIN. 1023 (2012) (discussing timing and strategic concerns in corporate decisions to repurchase stock).

91. Hamill, supra note 5, at 415-16.

92. See Cook, supra note 48.

93. See, e.g., Conti-Brown, supra note 50, at 409-10; Hansmann \& Kraakman, supra note 7, at $1880-81$.

94. See Richard A. Booth, Limited Liability and the Efficient Allocation of Resources, 89 Nw. U. L. REV. 140, 164 (1994); Frank H. Easterbrook \& Daniel R. Fischel, Limited Liability and the Corporation, 52 U. CHI. L. REV. 89, 91-92, 100 (1985). 
tion, such as those of Professors Henry Hansmann and Reinier Kraak$\operatorname{man}^{95}$ and David Leebron, ${ }^{96}$ as well as more recent efforts by Peter Conti-Brown, ${ }^{97}$ have focused on incentives to ameliorate excessive risk-taking by scaling back limited liability for shareholders.

However, there are other stakeholders whose liability is limited as a matter of course: creditors, managers, employees, and other contractual counterparties. ${ }^{98}$ Compared to shareholders, these parties can often exert as much if not more control over corporate policy. ${ }^{99}$ In addition, the financial return on debt instruments like high-yield bonds and leveraged loans (as well as more complex convertible debt instruments) can closely resemble the return on equity. ${ }^{100}$ This has led many scholars to conclude that the debt-equity distinction is at best ambiguous and at worst untenable. ${ }^{101}$

Professor Grundfest argues that even if limited liability for shareholders were unavailable, investors could easily obtain equity-like returns and limited liability. ${ }^{102}$ They could do so through changes to capital structure (i.e., replacing equity with debt), financial engineering, and by paying judgment-proof investors to hold the small portions of the capital structure that carry risk of unlimited liability. Similarly, Professor LoPucki has argued that businesses can easily avoid tort liability by partitioning their operations into operating entities that take risks and separate entities that own assets. ${ }^{103}$ The entities can organize their

95. Hansmann \& Kraakman, supra note 7, at 1879-81.

96. Leebron, supra note 44, at 1604-05.

97. Conti-Brown, supra note 50, at 416.

98. See Lynn M. LoPucki, The Essential Structure of Judgment Proofing, 51 STAN. L. REV. 147, 148 (1998); Steven Shavell, The Optimal Level of Corporate Liability Given the Limited Ability of Corporations to Penalize Their Employees, 17 INT'L REV. L. ECON. 203, 203 (1997); Sykes, supra note 44 , at 1241.

99. Douglas G. Baird \& Robert K. Rasmussen, Private Debt and the Missing Lever of Corporate Governance, 154 U. PA. L. REV. 1209, 1209 (2006) (highlighting the role of creditors in corporate governance); G. Mitu Gulati, William A. Klein \& Eric M. Zolt, Connected Contracts, 47 UCLA L. REV. 887, 926-27 (2000); Andrei Shleifer \& Robert W. Vishny, A Survey of Corporate Governance, 52 J. FIN. 737, 751 (1997).

100. As noted above, managers with certain compensation structures may also have equitylike incentives that encourage greater risk-taking and de facto limited liability.

101. Adam O. Emmerich, Hybrid Instruments and the Debt-Equity Distinction in Corporate Taxation, 52 U. CHI. L. REV. 118, 118-19 (1985); Joseph A. Grundfest, The Limited Future of Unlimited Liability: A Capital Markets Perspective, 102 YALE L.J. 387, 414-15 (1992); Edward D. Kleinbard, Stateless Income, 11 FLA. TAX REV. 699, 730 (2011); Katherine Pratt, The Debt-Equity Distinction in a Second-Best World, 53 VAND. L. REV. 1055, 1072-94 (2000); David A. Weisbach, Line Drawing, Doctrine, and Efficiency in the Tax Law, 84 CORNELL L. REV. 1627, 1648 (1999).

102. Grundfest, supra note 101, at 408.

103. LoPucki, supra note 98, at 149-50; Schwarcz, supra note 69, at 9. 
joint operations through contract rather than through shared ownership and corporate governance.

In addition, two empirical studies of transitions from unlimited to limited shareholder liability did not find much evidence of benefits redounding to shareholders. ${ }^{104}$ This raises questions about the classic view that shareholders are the primary beneficiaries of limited liability. Just as the burden of the corporate income tax probably does not fully fall on shareholders ${ }^{105}$ the benefit of limited liability may not exclusively accrue to them.

As previously noted, shareholders are indifferent to the magnitude of losses exceeding the point at which the value of their investment falls to zero. Creditors are similarly indifferent to the magnitude of losses exceeding the point where the value of their own investment falls to zero, and to losses which can be externalized to other creditors or lower-priority stakeholders. Because creditors have higher priority, losses are absorbed first by shareholders (up to the value of shareholders' investment in the firm), and then by creditors (up to the value of creditors' investment in the firm).

Consider a company that is financed with $\$ 50$ million of equity and $\$ 50$ million of debt. Shareholders will care about risks that reduce the value of the company from $\$ 100$ million to $\$ 50$ million. If this coincides with a default, equity's claim on the company may be extinguished and all value will then belong to the creditors. Creditors will care about risks that could reduce the value of the company from $\$ 50$ million to zero. But creditors will be indifferent to risks that could reduce the value of the company from zero to a negative value because all such losses will be externalized and fall on someone other than creditors.

Creditors are generally believed to seek to limit risk-taking because, unlike shareholders, creditors' upside is capped - the most creditors can gain is their principal and contractual interest payments. ${ }^{106}$ However, creditors will routinely trade looser covenants and fewer limits on corporate risk-taking in return for higher interest payments.

104. The first study is from California in the early twentieth century. Weinstein, California, supra note 49, at 3. The second is of a single company in the 1960s, American Express, that was primarily financed with short-term debt. Weinstein, American Express, supra note 49, at 190. The results may not be fully generalizable to modern companies that could face more substantial tort liability. Interestingly, the empirical case for secured creditors benefiting by externalizing risks to tort claimants is also contested. Listokin, supra note 33, at 1078.

105. See Li Liu \& Rosanne Altshuler, Measuring the Burden of the Corporate Income Tax Under Imperfect Competition, 66 NAT'L TAX J. 215, 233 (2013).

106. Simkovic \& Kaminetzky, supra note 48, at 214-18. 
Like shareholders, creditors enjoy limited liability. With high enough interest payments, creditors can obtain equity-like risks and returns.

Thus, investors who are creditors need not limit risk in ways that inadvertently protect nonadjusting creditors. It is easy for corporate managers acting in the interests of shareholders to coopt financial creditors by sharing with them the benefits of externalizing risks to third parties. If debt is already risky - that is, if debt has a high yield relative to the risk-free rate - this suggests that it is reasonably likely that creditors will not be paid in full unless profitability improves. In such situations, greater risk-taking (i.e., making unlikely but very negative outcomes more negative and relatively likely positive outcomes more positive) can provide upside to creditors.

High-yield debt and leveraged loans are often sufficiently risky that they resemble equity. The limited liability of investors who structure their investment as debt rather than equity can pose similar problems with respect to exacerbating the judgment-proof problem. Moreover, secured creditors' priority typically ensures that even if very negative outcomes materialize and the firm's liabilities exceed its assets by a wide margin, secured creditors will recover the lion's share of whatever assets are available. ${ }^{107}$ Indeed, impairing the rights of secured creditors arguably violates constitutional protections. ${ }^{108}$

Even unsecured or subordinated creditors will not fully price many risks that could be externalized to third parties. Creditors will be largely insensitive to risks that rarely materialize, but when they do materialize can be expected to exceed creditors' full investment and to therefore be externalized to third parties. ${ }^{109}$ In other words, like equity holders who benefit from limited liability entities, creditors can walk away from very large losses thanks to prevailing rules that limit liability

107. Bebchuk \& Fried, supra note 33, at 859; James Steven Rogers, The Impairment of Secured Creditors' Rights in Reorganization: A Study of the Relationship between the Fifth Amendment and the Bankruptcy Clause, 96 HARV. L. REV. 973, 973 (1983); cf. Mark J. Roe \& Frederick Tung, Breaking Bankruptcy Priority: How Rent-Seeking Upends the Creditors' Bargain, 99 VA. L. REV. 1235, 1276 (2013) ("In general, the most sophisticated, best organized, and best financed creditor groups are best positioned to pursue and obtain priority jumps than other types of credits.").

108. See Rogers, supra note 107, at 977 (questioning the argument that the uncompensated impairment of secured lenders' rights in bankruptcy proceedings violates the Fifth Amendment).

109. To be more precise, suppose Scenario A and Scenario B are equally likely. Scenario A would completely wipe out unsecured creditors, while Scenario B would completely wipe out unsecured creditors and cause massive harm to third parties as well. The difference in riskiness between Scenario A and Scenario B would not be reflected in market prices. 
of creditors and contractual counterparties to the size of their investment.

Thus, limited liability benefits financial creditors and managers, not just shareholders. An approach that targets shareholders, rather than firms' beneficiaries more broadly construed, is ill-equipped to address the challenges of limited liability. Extending Hansmann's analysis, this implies that pro rata unlimited liability should apply to financial investors in firms generally-shareholders, creditors, and warrantholders. While this would admittedly be a significant departure from customary practice and entail implementation challenges, it could mitigate loopholes in unlimited liability regimes noted by Professor Grundfest. ${ }^{110}$

How could proportionate unlimited liability be extended from shareholders to other investors? Liability would need to be roughly proportionate to the benefits investors receive from providing capital to finance a firm. And how could a system of unlimited liability for creditors as well as shareholders be compatible with a priority regime in which losses are borne by shareholders first and creditors last?

Liability could be weighted according to both the aggregate value and timing of investors' holdings. That is, liability exceeding the unencumbered assets of the firm and its insurance coverage would be proportionate to investors' holdings in the firm during the time periods when the firm undertook actions that likely caused harm, and not simply during the later period when the harm materialized.

Each investor's proportionate interest in the firm could be measured as the weighted average price of the investor's holdings in the firm divided by the total market value of the firm, including stock, debt, warrants, and options. ${ }^{111}$ This would typically not be measured as of a

110. I say mitigate rather than eliminate because investors would likely devise creative approaches to benefit from a firm's activities without incurring potential liability as a financial investor. For example, lessors and licensors resemble secured creditors. But if substitutes for investors are not treated as investors for purposes of proportionate unlimited liability, firms could offer some backers limited liability by leasing their assets and licensing their intellectual property rather than borrowing money from them to buy or develop the same assets. Policing the boundaries of a firm and defining "financial investors" would be challenging. Nevertheless, including broader groups of investors, and not just shareholders, would make a proportionate unlimited liability regime harder to evade.

111. When precise market valuations of debt, equity, and warrants are not available, proxies like enterprise value may be used. Enterprise value is the market value of a firm's equity plus the book value of its debt, less cash. TIM KOLlER, MARC GOEDHART, \& DAVID WESSEls, VAluation: MeAsuring AND MANAGING THE VAlue OF COMPANIES 103 (5th ed. 2010). 
single point in time, but rather averaged over several time periods, because it may not be possible to pinpoint precisely when the harm was caused-for example, for toxic or long-manifesting torts. ${ }^{112}$

Thus, for example, if an investor owned 10 percent of the total value of the firm during 20 percent of the time period during which firm activities caused harm, the investor would be liable for 2 percent of the firm's liability exceeding the firm's unencumbered assets and insurance coverage.

\section{F. How big of a problem?}

How large are the unknown risks and costs that companies may externalize? This question is inherently difficult to answer precisely because the risks are unknown. However, attempts to estimate the magnitude of externalization of known risks suggest that the problem is substantial enough to merit additional policy interventions.

In the mid-1990s, Ralph Estes, a CPA, sought to measure the aggregate "social costs" of business enterprise, which Estes defined as costs imposed on society that are neither internalized nor accounted for by firms. ${ }^{113}$ Factoring in workplace injuries and accidents, medical expenses from unsafe products, and health costs from pollution, Estes found that external costs to U.S. taxpayers totaled approximately \$2.618 trillion in 1994 dollars. ${ }^{114}$ His analysis does not distinguish between corporate and noncorporate firms, but instead encompasses all business enterprise in the United States. ${ }^{115}$ Adjusted only for inflation, ${ }^{116}$ this estimate in 2017 would be approximately $\$ 4.3$ trillionmore than 20 percent of U.S. GDP. ${ }^{117}$

In reaching this number, Estes combined original research with "specific corporate social costs [that] have been estimated in a variety

112. Christopher F. Edley Jr. \& Paul C. Weiler, Asbestos: A Multi-Billion-Dollar Crisis, 30 HARV. J. ON LEGIS. 383, 384-86 (1993) (discussing challenges relating to the timing of exposure and illness in the toxic-torts context).

113. ESTES, supra note 12, at 171.

114. Id. at $177-78$.

115. Id. at 172 .

116. See CPI Inflation Calculator, U.S. BUREAU OF LABOR STATISTICS, https://www.bls.gov/data/inflation_calculator.htm [https://perma.cc/E3DQ-GY4A] (last visited July 3, 2018). \$2.618 trillion in December of 1994 is equal to \$4.311 trillion in December of 2017. Id.

117. U.S. GDP in 2017 was approximately $\$ 19.391$ trillion. BUREAU OF ECON. ANALYSIS, U.S. DEP'T OF COMMERCE, Gross Domestic Product: Fourth QUARTER AND ANNUAL 2017 (THIRD ESTIMATE) 8 tbl.3 (2018), https://bea.gov/newsreleases/national/gdp/2018/pdf/ gdp4q17_3rd.pdf [https://perma.cc/HU56-XJSX]. Note that 4.311 divided by 19.391 is 22 percent. 
of contexts." ${ }^{118}$ Estes does not purport to find a precise figure, but rather claims to reach a conservative estimate. ${ }^{119}$ Estes's estimate of the public cost of private corporations includes four categories: (1) costs to workers; (2) costs to customers; (3) costs to communities; and (4) costs to the nation. ${ }^{120}$

Within these categories, the largest costs are deaths from workplace cancer ( $\$ 274.7$ billion), price-fixing conspiracies, monopolies, and deceptive advertising ( $\$ 1.2$ trillion), and health issues caused by air pollution ( $\$ 225.9$ billion). ${ }^{121}$ Estes argues that this estimate is conservative because "only costs that are directly identifiable have been estimated," whereas "other social costs, as well as secondary and multiplier effects, have generally been omitted." 122 Estes does not include the cost of serious poisonings from pesticides or the cost of psychological human suffering. ${ }^{123}$

There are numerous methodological challenges with this approach - the estimates used come from distinct studies conducted by numerous organizations and researchers at different times using varying methodologies. ${ }^{124}$ Estes's inclusion of monopoly pricing is perhaps stretching the definition of "externalization." However, twenty years later, Estes's study remains one of the most comprehensive and widely cited studies of aggregate externalization costs.

A more recent and less ambitious estimate from 1999 tabulates specific costs that add up to nearly $\$ 900$ billion in 2017 dollars. ${ }^{125}$ In 1999 dollars, these included $\$ 53.9$ billion in annual health costs from cigarettes, $\$ 135.8$ billion for the consequences of unsafe vehicles, $\$ 141.6$ billion for injuries and accidents in unsafe workplaces, and $\$ 274.7$ billion for cancer deaths caused by toxic exposure in the workplace. ${ }^{126}$ In total and adjusting for inflation to 2017 dollars, these four product categories represent an estimated $\$ 897$ billion in externalization costs, or around 4 to 5 percent of GDP.

118. ESTES, supra note 12 , at 172.

119. Id. at 173 .

120. Id. at $177-78$.

121. Id. at 177 .

122. Id. at 173 .

123. Id. at 182 .

124. Id. at 173 .

125. See DAvid C. Korten, The Post-Corporate World: LifE After CAPITAlism 4683 (1999); CPI Inflation Calculator, supra note 116.

126. KORTEN, supra note 125 , at 48. 
Even if Estes's estimate is too high by a factor of five, it still suggests that the magnitude of externalization is large enough to cancel out annual economic growth as measured by GDP. ${ }^{127}$ This merits policymakers' attention.

Some might argue that limited liability only facilitates externalization when a company becomes insolvent. Because corporate insolvencies are relatively rare, one might think that the role of limited liability in externalization is small. But this line of reasoning overlooks the role of potential insolvency and the limits of successor liability in deterring plaintiffs. Actual insolvency is unnecessary for limited liability to facilitate loss externalization. The mere specter of liability pushing a firm to the brink of insolvency might persuade regulators, courts, and plaintiffs to agree to lower damages, or forgo litigation altogether, rather than expend resources seeking damages that would be uncollectible. ${ }^{128}$

Companies' existence often ends with an asset sale rather than an insolvency. Following the asset sale, proceeds are distributed to target company investors, and the target company dissolves. In most jurisdictions, asset purchasers do not take on successor liability. ${ }^{129}$ Nevertheless, cautious acquirers often use an acquisition subsidiary - which provides a liability shield to the parent company - to mitigate the risks of successor liability. Limited liability reduces the risk of claimants injured by the target pursuing the acquirer of the target's assets. Thus, limited liability facilitates externalization even in the absence of corporate insolvency.

\section{PREVIOUS SOlUtionS AND THEIR LIMITATIONS}

Several policy tools have been proposed to address the judgmentproof problem when dealing with activities that are known ex ante to be risky, including safety regulation, minimum asset requirements, and compulsory insurance. ${ }^{130}$ These tools could arguably also be used to address the broader risk of externalization through limited liability, but

127. Since 1990, U.S. real GDP growth has averaged around 2.5 percent per year. Real Gross Domestic Product, FRED: ECON. DATA (July 27, 2018), https://fred.stlouisfed.org/series/ A191RL1A225NBEA [https://perma.cc/TFH6-AGGZ].

128. See Merritt \& Barry, supra note 60.

129. Restatement (Third) OF Torts: Prod. Liab. \$ 12 (AM. LAW. InST. 1998); Asset Purchase Agreement Commentary, PRACTICAL LAW CORP. \& SEC., Westlaw (last visited July 3, 2018) https://us.practicallaw.thomsonreuters.com/4-381-0590.

130. Shavell, Liability for Harm, supra note 32, at 357; Steven Shavell, Minimum Asset Requirements and Compulsory Liability Insurance as Solutions to the Judgment-Proof Problem, 36 RAND J. ECON. 63, 63-77 (2005) [hereinafter Shavell, Minimum Asset Requirements]. 
each tool comes with limitations and offers an incomplete solution. It is particularly difficult to use these tools to address risks that are unknown or unknowable. It is not always feasible to identify in advance which activities are risky. ${ }^{131}$

\section{A. Unlimited liability is limited by collection challenges}

Providing for unlimited investor liability - in a way that would be difficult for investors to circumvent and that would facilitate substantial recoveries - is challenging. Restricting limited liability seems attractive because retroactive assessments against investors could be proportionate to the damages caused and the risks taken. The level of risk and potential harm may be difficult to determine ex ante, but easier to determine ex post. As a practical matter, however, ex post unlimited liability entails serious challenges of collections and enforcement. The prospect of unlimited liability could also exacerbate information problems and capital structure conflict among investors. ${ }^{132}$ However, these problems can be mitigated if unlimited liability for torts (and tort-like civil penalties) is proportionate rather than joint and several. ${ }^{133}$ Circumvention efforts via exotic structures can be curtailed if proportionate liability applies broadly to all financial investors. ${ }^{134}$

However, the practical challenges of gathering information about and collecting judgments from international investors (or U.S. investors investing through foreign corporations) are not as large or insurmountable as is often assumed. ${ }^{135}$ Much of the information that would be needed has already been gathered through international cooperation to stymie funding for terrorism, prevent money laundering, and curb tax evasion. ${ }^{136}$ The U.S. and European Union ("E.U.") have successfully pressured tax havens-including those with bank secrecy laws - to reveal information about investors and thereby facilitate enforcement of U.S. law and the laws of large E.U. member states. ${ }^{137}$ If

131. Levitin, supra note 19, at 452 (arguing that whether a firm is too big to fail is "inherently speculative").

132. See supra notes $44-47$ and accompanying text.

133. See supra note 56 and accompanying text.

134. See supra Part II.E.

135. Contra Grundfest, supra note 101, at 398 ("Simply identifying foreign shareholders and locating their assets can be daunting."); $i d$. at n.44 ("Identifying foreign owners can be virtually impossible when ownership must be traced through bearer shares, such as those issued by Liechtenstein ... or when ownership is held through accounts in jurisdictions with bank secrecy laws.”).

136. See JAMES K. JaCKSON, The OECD InItIATIVE ON TAX HAVENS 1, 6 (2010).

137. Niels Johannesen \& Gabriel Zucman, The End of Bank Secrecy? An Evaluation of the 
necessary, the U.S. and E.U. can bring significant economic and political pressure to bear on smaller states, which usually results in those states cooperating with law enforcement efforts. ${ }^{138}$

Another problem is that unlimited liability removes the insurancelike benefits of limited liability for risk-averse investors. Although investors or firms can voluntarily insure some risks privately, risks that are not yet well-understood may not be privately insurable. In addition, the insurance company may face its own solvency challenges if large harms materialize.

\section{B. Safety regulation is limited by regulators' knowledge of which activities are unsafe}

Safety regulation is an attractive approach for managing risks when regulators have good information about the nature of the risks, precautions that can be undertaken to reduce those risks, and how the costs and benefits of various precautions compare to one another. ${ }^{139}$ Regulation may be particularly attractive when regulators have specialized technical knowledge beyond that possessed by most private parties, and economies of scale in acquiring and maintaining that knowledge. ${ }^{140}$ In particular instances, however, private actors may have better information than regulators about risk. When private actors have better information than regulators, liability and other methods of internalizing costs should move industry closer to the optimal risk levels. ${ }^{141}$

G20 Tax Haven Crackdown, 6 AM. ECON. J.: ECON. POL'Y 65, 69 (2014).

138. Michael A. Berger, Not So Safe Haven: Reducing Tax Evasion by Regulation Correspondent Banks Operating in the United States, 12 J. INT’L BUS. \& L., 51, 80-81 (2014).

139. See Iman Anabtawi \& Steven L. Schwarcz, Regulating Ex Post: How Law Can Address the Inevitability of Financial Failure, 92 TEX. L. REV. 75, 128 (2013) (noting that "(1) the more confident regulators are in their ability to model the dynamics of the financial system, (2) the more controls exist for regulating systemically significant activities, and (3) the more capable regulators are at implementing their policies without giving rise to substantial market inefficiencies or regulatory arbitrage," the more regulators should use ex ante regulation); Levitin, supra note 19, at 439, 461-78 (describing challenges and limitations of ex ante approaches to reducing systemic risk in financial and nonfinancial firms); Brian Galle, In Praise of Ex Ante Regulation, 68 VAND. L. REV. 1715, 1724 (2015) ("With perfect government information, perfectly rational actors, and complete liquidity, ex post is equivalent to ex ante. ... In the case of a manufacturer or retailer that expects subsequent liability, the present discounted value of the expected future liability becomes part of the costs of production."); Shavell, Liability for Harm, supra note 32, at $368-71$.

140. Shavell, Liability for Harm, supra note 32, at 369.

141. Id. at 366-67. 


\section{Minimum asset requirements reduce competition}

Minimum asset requirements might inefficiently prevent parties with low assets from engaging in socially beneficial activities and could inefficiently reduce entrepreneurship and competition. ${ }^{142}$ While this side effect might not be particularly troubling if the policy were exclusively applied to activities known to be high-risk, broadly applying minimum asset requirements whenever limited liability is utilized could have much greater economic consequences.

\section{Insurance requires measurable risk and policing moral hazard}

Private insurance is generally not readily available for unknown or unknowable risks. Insurers generally prefer to underwrite insurance for well-understood, specific, and readily quantifiable risks for which historical data is available - that is, risks that resemble those that have materialized in the past. ${ }^{143}$ Compulsory insurance is attractive when it is possible for insurers to observe differences in risk levels and levels of care across insured parties and adjust the cost of insurance accordingly. Risk-adjusted premiums can affect both the decision about whether to engage in a risky activity and the level of care to take if engaging in the activity. ${ }^{144}$ However, if premiums are not risk-adjusted, insurance can introduce moral hazard and adverse selection problems and blunt incentives to take precautions once insured. ${ }^{145}$

Mandatory insurance also does not eliminate the judgment-proof problem, but rather shifts it up the chain to the insurance company. ${ }^{146}$ During the financial crisis of 2008, several insurance companies that took on correlated mortgage risks, such as monoline insurers and AIG,

142. Shavell, Minimum Asset Requirements, supra note 130, at 64-65. The problem is more severe when the ability to raise capital is constrained, for example because of information problems or other frictions in the capital markets.

143. Howard Kunreuther \& Mark Pauly, Insuring Against Catastrophe, in THE KNOWN, THE UNKNOWN, AND THE UNKNOWABLE IN FINANCIAL RISK MANAGEMENT: MEASUREMENT AND Theory Advancing Practice 210, 211 (Francis X. Diebold, Neil A. Doherty \& Richard J. Herring eds., 2010); Boardman, supra note 9, at 784.

144. Omri Ben-Shahar \& Kyle D. Logue, The Perverse Effects of Subsidized Weather Insurance, 68 STAN. L. REV. 571-628 (2016); Hanson \& Logue, supra note 18, at 1268-80.

145. Shavell, Minimum Asset Requirements, supra note 130, at 64-65.

146. Cf. Boardman, supra note 9 , at $806,807,809,812$ (noting that mandatory insurance required under the Terrorism Risk Insurance Act merely shifts the risk to insurance companies, who are compensated by the federal government in case of insolvency). 
faced their own solvency challenges which ultimately led to post hoc liquidity support from the federal government. ${ }^{147}$

Even if private insurance is not enough by itself, why should private insurance not play a larger role and supplant the role of the government in providing limited liability, to the extent possible? As previously noted, private insurance companies only provide insurance for specific, well-understood and clearly defined risks for which there is actuarial information available. Insurance companies need this information to price premiums and ensure profitability. Insurance contracts contain exclusions to make the insured risks highly specific. Private insurers only provide insurance up to specified limits of coverage.

In contrast, limited liability is effectively all-purpose insurance for anything that might go wrong with no coverage limit - the effective limit is all of the nonexempt assets of the investors. Limited liability covers gaps that private insurance does not cover. Private insurance could serve as a fallback for companies that think limited liability is too expensive, but it would likely be inferior and chosen solely for its lower cost.

Relying on a private insurance company raises questions. Who insures the insurance company? What happens when the insurance company becomes insolvent? If one believes that private insurers are more competent than government agencies at pricing even poorly understood risk, one possible approach to harness their expertise would be to require private insurance for specific tranches of risk (for example, private insurance to cover 5 percent of the first $\$ 1$ billion in risk, 5 percent of the billion between $\$ 10$ billion and $\$ 11$ billion, and so on). However, if the tranches were too large, the private insurance company would risk insolvency. If tranches were too small, there would be little incentive for the insurance company to invest in pricing risk appropriately.

If rates for a small tranche of private insurance were used to price a much larger government limited liability program, then diversified insurers who serve large corporate clients in many capacities would have strong incentives to undercharge for a small amount of limited

147. Robert P. Bartlett, III, Inefficiencies in the Information Thicket: A Case Study of Derivative Disclosures During the Financial Crisis, 36 J. CORP. L. 1, 15 (2010); Michael Simkovic, Competition and Crisis in Mortgage Securitization, 88 IND. L.J. 213, 213 (2013); Michael Simkovic, Secret Liens and the Financial Crisis of 2008, 83 AM. BANKR. L.J. 253, 283-89 (2009); Squire, supra note 67 . 
liability insurance. The insured could covertly compensate private insurance companies for misleading the government by providing cooperating insurance companies larger, more lucrative insurance contracts in other areas. This is analogous to the conflicts of interest that plague auditors who provide lucrative consulting work to their auditing clients, investment banking analysts who cover client companies, or credit rating agencies that compete with one another to provide lucrative services to issuers. Related problems recently arose in the Hovnanian case, ${ }^{148}$ in which a buyer of credit-default-swap protection allegedly paid an issuer to manipulate the pricing of a small number of bonds, which were used to price the much larger market for credit derivatives referencing Hovnanian securities. ${ }^{149}$

Private insurance would not reveal information about private risk estimates in the same way that elections within a public program could, even under the best of circumstances in which there were mandatory disclosure of insurance rates, terms, and underwriting criteria. However, requiring private insurers to disclose their pricing, terms, and client bases, and banning conflicting lines of business would make limited liability insurance an extremely unattractive line of business. In sum, the advantages of basing pricing for limited liability on private insurance rates may be outweighed by greater complexity, conflicts of interest, and reduced transparency.

\section{A PROPOSED SOLUTION: LIMITED LIABILITY AS AN INFORMATION-FORCING MECHANISM}

Limited liability as it currently exists operates as uncapped, mispriced insurance. Beneficiaries of limited liability are provided protection from risks, regardless of their likelihood or potential costs, for free. This results in an externalization problem that solutions such as regulation, mandatory insurance, and minimum capital requirements can help mitigate, but only insofar as policymakers understand industryspecific risks.

A solution is to use limited liability as an information-forcing mechanism. By charging firms for limited liability, private entities would be forced to reveal information about industry-specific risks to

148. Solus Alt. Asset Mgmt. LP v. GSO Capital Partners, L.P., No. 18 CV. 232-LTS-BCM, 2018 WL 620490 (S.D.N.Y. Jan. 29, 2018).

149. Id. at *2-3, *5-9; Robert K. Rasmussen \& Michael Simkovic, Fairness Without Standards 8-9 (Aug. 5, 2018) (unpublished manuscript) (on file with Duke Law Journal) (explaining the Hovnanian deal structure). 
policymakers. The charge, if well-calibrated to risk levels, could also help compensate the public fisc for risks, thereby reducing the externalization problem.

For a limited liability charge to operate as an information-forcing mechanism, three features would be very helpful. First, the cost of opting into limited liability should be determined iteratively to allow regulators to reprice limited liability in subsequent periods based on information received in the previous period. Second, because the most obvious correlate of externalization risk is probably size or activity level, the appropriate tax base is the greater of revenue or expenditures. Third, non-risk-related factors that could influence a firm's election-investor wealth, risk aversion, agency costs, capital structure, and positive externalities - should be considered.

\section{A. Dynamic, iterative pricing of the unknown}

The goal of a limited liability tax is to target risks of harm that may be externalized to third parties. Pricing the unknown is inherently challenging, particularly when regulators and tax authorities have far less information than industry participants and sophisticated investors.

Conventional approaches to measuring risk used in finance and the asset pricing literature are of limited usefulness because these measures are meant to assess risk to investors-either shareholders or creditors - who enjoy limited liability. ${ }^{150}$ When investors enjoy limited liability, they will only consider risks up to the value of their investment, not risks of harm that can be externalized to the general public. ${ }^{151}$ The fact that risks are not known and are not precisely quantifiable does not mean that nothing should be done to address them. We can

150. For example, some scholars have proposed that courts and regulators use market indicators of risk, such as credit spreads, to detect risks that have not yet materialized and are not readily observable. Oliver Hart \& Luigi Zingales, A New Capital Regulation for Large Financial Institutions, 13 AM. L. ECON REV. 453, 487-88 (2011) (proposing an equity capital requirement that relies on CDS prices rather than credit rating agencies); Simkovic \& Kaminetzky, supra note 48, at 166-68 (proposing that courts focus on credit spreads rather than bond prices or yields); Michael Simkovic, Making Fraudulent Transfer Law More Predictable 157 (Seton Hall Law Sch. Pub. Law \& Legal Theory Research Paper Series, 2016), http://ssrn.com/abstract=2775920 [https://perma.cc/H8PC-WVGN]; Michael Simkovic, The Evolution of Valuation in Bankruptcy, 91 AM. BANKR. L.J. 301, 307 (2017). Markets, imperfect though they may be, tend to be better at aggregating information and predicting the future than many alternatives. However, credit spreads and other financial-market-based indicators of risk can account for risks only to the extent that those risks would be borne by creditors or other investors.

151. See supra notes 105-09 and accompanying text. Market participants focus only on their own bottom lines and not on externalities. Robert K. Rasmussen \& David A. Skeel, Jr., The Economic Analysis of Corporate Bankruptcy Law, 3 AM. BANKR. INST. L. REV. 85, 94 (1995). 
safely assume that the costs of externalized risks - and the commensurate benefits to investors and employees - are greater than zero. Thus, even a modest countervailing policy could be an improvement over the status quo.

Industry participants' choice to pay the proposed fee for limited liability or forgo protection will reveal information to policymakers and regulators about knowledgeable parties' internal assessments of risk. Indeed, the requirement that firms and investors make choices with respect to limited liability - difficult choices that entail substantial financial tradeoffs - will encourage firms and investors to gather information and assess risks that they might otherwise ignore.

When limited liability comes at a cost, those who believe that they are engaged in riskier activities will be more likely to opt into limited liability, while those who believe their actions are comparatively benign will be more likely to forgo it. ${ }^{152}$ If limited liability were priced uniformly relative to scale, then variation in the proportion of similar firms that opted into limited liability would reveal information about private assessments of the relative riskiness of various activities. Assume risks are nearly uniform within a group of similar firms, but information about risk and perceptions of risks still vary among members of the group. ${ }^{153}$ Thus, elections regarding limited liability aggregate and reveal information about risk, much as market pricing or prediction markets aggregate and reveal information. ${ }^{154}$ Regulators could use this information to more closely study and eventually regulate or insure high-risk activities.

Regulators could also iteratively reprice limited liability in subsequent periods, charging different prices to different risk-pooled groups of firms based on information revealed in the previous period. Thus, a risk-uniform group in which relatively few or no firms opted into limited liability in the previous period-thereby signaling relatively low risk for the group-would see the price of limited liability fall in the next period. On the other hand, a risk-uniform group in which a very

152. Ayres \& Gertner, supra note 26, at 98-100; Raskolnikov, supra note 26, at 691.

153. In other words, risks are uniformly distributed within each group, but perceptions of risk are nonuniformly distributed. A simplifying assumption is that such information is normally distributed.

154. See Gilson \& Kraakman, supra note 28, at 585-86 (discussing how price equilibration for innovative securities proceeds rapidly as more traders become informed); Grossman, supra note 28 (discussing how the equilibrium price summarizes the aggregate of all the information in a competitive market); Wolfers \& Zitzewitz, supra note 28, at 112 (describing how prediction markets have outperformed polling organizations in the political domain). 
large proportion of firms opted into limited liability - thereby signaling relatively high risk - would see the price of limited liability increase in subsequent periods. Limited liability during each period would cover harm arising out of activities undertaken during the period. Because the benefits of making the proper election are fully internalized by individual firms, whereas the costs of future regulation or limited liability tax changes will be borne collectively by the group (i.e., competitors within an industry), firms will be unlikely to strategically mislead policymakers through their elections. ${ }^{155}$

When prices are set such that similar firms are close to equally likely to choose limited liability or forgo it, we can infer that the cost of limited liability is priced roughly at its value. ${ }^{156}$ At this point, differences in the price of limited liability for different categories of firms would be a good indicator of differences in residual risk that are known or suspected by industry participants, but unknown to regulators or the public. These price adjustments constitute an optimization process, and it therefore makes sense to initially price at a "best guess" of where the price will eventually settle. In light of (admittedly tentative) estimates that the externalization problem could amount to around 4 to 5 percent of GDP, it may be sensible to initially price limited liability at least at 4 to 5 percent of revenue. ${ }^{157}$

Costly limited liability will require both managers and investors to assist with risk assessment. If limited liability is costly enough, firms will invest resources in understanding risks they would otherwise ignore, to better understand whether limited liability is worth the price. If a firm overpays for limited liability, then investors may decline to invest, sell their holdings, or short sell the company and publicize its shortcomings; firms that agree to overpay for acquisitions will often see their share price decline when the deal is announced. ${ }^{158}$

Alternatively, investors might reject a decision by management to forgo limited liability. If a firm elects unlimited liability against the better judgment of investors, those investors could sell their holdings (or

155. Collusion becomes more plausible if the group is very small and/or the industry is highly consolidated.

156. If one assumes some risk aversion, then the optimal price may be one at which more than half of firms choose limited liability, though not all. If all firms choose limited liability, that would be a clear sign that limited liability is underpriced.

157. See supra Part II.F.

158. Randall Morck, Andrei Shleifer \& Robert W. Vishny, Do Managerial Objectives Drive Bad Acquisitions?, 45 J. FIN. 31, 31 (1990) (noting that shareholders experience a decline in wealth when managers overpay in acquisitions). 
short sell). Or investors could place their holdings in a limited liability vehicle. Passive investors who place their holdings in a limited liability vehicle would simply pay their pro rata share of the limited liability fee-that is, what the portfolio company would have paid on their behalf had it elected limited liability. Activist investors might have to pay an additional fee for limited liability to reflect additional risks associated with their activities. ${ }^{159}$ The portfolio company would be recorded for purposes of iterative pricing as if it was partially limited liability and partially unlimited liability based on the share of total firm value held by investors who opted for limited liability. Thus, an investor would be able to unilaterally override managers' choice to forgo limited liability with respect to the investor's own holdings. Decisions by insiders to use private insurance or place their own shares in limited liability entities would implicate fiduciary duties and mandatory disclosure requirements.

Investors and active money managers would likely independently gather information and form their own judgments. When enough money is at stake, activist investors, arbitrageurs, and short sellers use information-gathering techniques such as interviews with former employees, customers, vendors, and suppliers. Investors purchase proprietary data and engage outside experts to analyze it. Some investors use even more exotic approaches to information gathering such as drone surveillance or consultancies staffed with experienced intelligence officers. ${ }^{160}$ The worse the decisions made by managers, and the more money to be made correcting or exploiting those bad decisions, the more resources investors will deploy to gather information.

For the purpose of grouping firms, a natural starting point would be extant classification systems, such as the North American Industry Classification System (NAICS). ${ }^{161}$ NAICS and its predecessor, the

159. Passive investors do not attempt to alter how a firm is governed, but rather attempt to select firms that will perform well. Activist investors use a variety of tactics to try to change corporate strategy and to benefit themselves (though not necessarily the rest of the shareholders). Some of these tactics can create liability risk for the activist investor. Iman Anabtawi \& Lynn Stout, Fiduciary Duties for Activist Shareholders, 60 STAN. L. REV. 1255, 1258, 1260-61 (2008).

160. Eamon Javers, Accountants and Spies: The Secret History of Deloitte's Espionage Practice, CNBC (Dec. 19, 2016, 10:59 AM), https://www.cnbc.com/2016/12/19/accountants-and-spiesthe-secret-history-of-deloittes-espionage-practice.html [https://perma.cc/6E2L-754N]; Madison Marriage, Hedge Funds Turn to Spy Technology, FIN. TIMES (Sept. 15, 2013), https://www.ft.com/content/228bfc86-1c91-11e3-8894-00144feab7de [https://perma.cc/ 2T3P-86EV].

161. U.S. CENSUS BUREAU, NORTH AMERICAN INDUSTRY CLASSIFICATION SySTEM (2017) [hereinafter NAICS]. 
Standard Industry Classification system (SIC), are widely used by the federal government for data collection and are also used by investors. NAICS is updated every five years as new technologies develop and new industries emerge. ${ }^{162}$ It is also compatible with the International Standard Industrial Classification system (ISIC). ${ }^{163}$

Regulators may be able to risk-pool firms only imperfectly; firms within a group will inevitably be less than perfectly uniform. But this too can be an information-forcing mechanism that could lead to dynamic improvements over time. Low-risk firms that are mistakenly grouped with high-risk firms have incentives to reveal industry-specific information that can help regulators and policymakers better distinguish between high-risk and low-risk firms.

Whatever price is initially implemented for a limited liability tax will divide the population of taxpaying businesses into three groups: (1) those for whom the tax is lower than the perceived value of limited liability, and who therefore will choose a limited liability entity and pay the tax; (2) those for whom the tax is higher than the value of limited liability, and who will therefore do business without the benefits of limited liability (but perhaps with more private insurance than they would otherwise use); and (3) those for whom the tax is higher than the value of limited liability, and who will refuse to do business without the benefits of limited liability. The decision by Group (3) firms to not do business will likely improve efficiency by shutting down socially harmful firms. ${ }^{164}$

162. Id. at 3; U.S. Census Bureau, NAICS UPDATE Process FACTSHeET 1, https://www. census.gov/eos/www/naics/reference_files_tools/NAICS_Update_Process_Fact_Sheet.pdf [https://perma.cc/UL8D-EE62].

163. NAICS, supra note 161, at 3; UNITED NATIONS, INTERNATIONAL STANDARD INDUSTRIAL CLASSIFICATION OF ALL ECONOMIC ACTIVITIES (ISIC) 37 (rev. 4, 2008), https://unstats.un.org/unsd/publication/seriesm/seriesm_4rev4e.pdf [https://perma.cc/RQF7-JYS7].

164. This is likely as long as either investors are not risk averse or the firm or its investors can seek private insurance as an alternative to limited liability. If investors are risk neutral or riskseeking and have decided that a business is not attractive-whether they pay for limited liability or forgo it - then the business is likely socially harmful and should not operate. Thus, shifting some businesses into Group (3) will increase efficiency by shutting down socially harmful businesses.

However, if Group (3) firms' investors are risk averse, then Group (3) firms or their investors could seek private insurance in lieu of limited liability. Only if all private insurance companies were unwilling to insure risks at a lower cost than the government - and were all mistaken in this decision - would overcharging for limited liability create a deadweight loss. To obtain private insurance, firms would likely have to be extremely specific about which risks they wished to insure and would therefore need to reveal information to private insurance companies. Investors would also have to feel confident that risks would be below insurance coverage limits and that the insurance company could remain solvent. These are serious shortcomings, but private insurance could 
There will be a margin for error in pricing where taxpayers are risk averse, because the value risk-averse taxpayers place on limited liability will be higher than the cost to the government of providing limited liability (i.e., the cost of absorbing additional externalized losses), just as the insured value insurance more than it costs the insurance company to provide it. If policymakers believe that investors are risk averse and that private insurance is unavailable because private insurance companies are also irrationally risk averse, then the optimal proportion of firms electing limited liability would be more than half. The optimal proportion would be larger depending on the degree of investor risk aversion assumed.

The limited liability tax could improve on the status quo for both Groups (1) and (2) by forcing them to internalize more costs and providing fewer opportunities for externalization. Group (1) will internalize part of the cost by paying a tax, while Group (2) will internalize costs by paying more in judgments. Firms' choices about which group to join can convey important information to regulators.

If firms choose to transition between limited liability and unlimited liability in future periods, investors in transitioning firms may seek to liquidate their positions. Changes in the market price of firms would also reveal information about investors' assessments of risk. This approach might put pressure on the agency relationship between managers and investors. Managers might have incentives to either exaggerate or understate externalization risks, depending on their own levels of risk aversion. Nevertheless, U.S. corporate and securities laws, and sophisticated investors generally, are effective at monitoring managers, aligning their interests with investors, and policing agency costs. Corporate law is a strong enough pillar to support risk discovery.

Thus, the limited liability tax is an information-forcing mechanism that encourages businesses to publicly reveal private information about the risks of externalization inherent in their businesses. ${ }^{165}$ Lawmakers, regulators, and insurers can therefore focus more of their attention on Group (1) entities that have identified themselves as high risk. ${ }^{166}$ While

nevertheless provide a less expensive - and less attractive - alternative to limited liability, which could mitigate the danger of the government overcharging for limited liability.

165. See, e.g., Raskolnikov, supra note 26, at 691 (proposing information-forcing and self-sorting mechanisms in tax enforcement).

166. Regulatory focus on individual firms that opt into limited liability would likely be priced into individual firms' decisions about entity selection. However, if regulators and insurers note the mix of firms that opt into limited liability versus unlimited liability by industry or activity type, 
the limited liability tax will be mispriced at any given point in time, it can accelerate the risk-discovery process. Thus, it will increase dynamic efficiency and provide long-term benefits.

\section{B. Choosing a tax base to scale firms}

The iterative approach to taxing limited liability outlined above requires that similar firms be grouped together. To form larger groups, it is helpful to scale limited liability tax rates by firms of different size to arrive at different tax liabilities. If two firms are engaged in activities that are similarly risky, but one firm's activities are more extensive, the firm engaged in more extensive activities should pay a greater tax. This is fundamentally a question of the appropriate tax base. For reasons explained in greater detail below, the appropriate measure of activity, and therefore the appropriate tax base, is probably the greater of revenue or expenditures.

The most obvious correlate of externalization risk is probably size or activity level. All else being equal, a larger business enterprise, more actively engaged in the economy, is likely to produce larger losses in a downside scenario than a much smaller, less active enterprise. Larger aggregate losses are probably more likely to lead to government intervention than smaller ones (although a network of small enterprises engaging in similar activities could, in the aggregate, generate large externalized losses).

1. The greater of revenue or expenditures. Revenue has many advantages as a measure of size and economic activity. Revenue reflects the value that the market is willing to pay for the total output of a firm on an annual basis. In the absence of specific information that certain activities are riskier than others per unit of revenue, revenue seems like a sensible starting place for sizing risk. Unlike profit and income, revenue does not depend on capital structure-regardless of the mix of debt or equity, revenue remains constant. Unlike income, ${ }^{167}$ revenue is not easy to alter through simple accounting manipulations, such as characterizing certain cash outlays as current expenses or disguising dividends or personal consumption as business expenses.

and increased policing and monitoring of those industries and activities across entity types, collective action problems would preclude too much gamesmanship by firms with respect to entity selection.

167. See Hamill, supra note 5, at 415-19 (discussing closely held corporations' generally successful attempts to bring taxable corporate income down to nearly zero by boosting deductible expenses). 
Indeed, revenue-sharing agreements have often been used to coordinate activity across firms in a supply chain. ${ }^{168}$ Some analyses suggest that revenue sharing could have advantages over profit sharing in many contexts. ${ }^{169}$

Some scholars have also argued that a heavy income tax does not discourage risk-taking as long as there are full loss offsets and taxpayers can adjust their portfolios in response to the tax. ${ }^{170} \mathrm{~A}$ revenue tax, unlike an income tax, does not feature loss offsets of any kind. Therefore, it may be sensible to structure a limited liability tax as a percentage of the revenue of any entity that confers limited liability on its investors.

However, firms will only have revenue if they have customers. Firms might undertake risky investment activities in early stages when they have no revenue. For such firms, cost may be a better measure of size of economic activity. Therefore, the greater of revenue or cost may be the best available tax base.

Tax scholars concerned only with raising revenue to fund public programs tend to frown on revenue taxes because revenue taxes disadvantage low-margin firms and therefore are more likely than income taxes to discourage low-margin but profitable firms from operating. ${ }^{171}$ However, for the purpose of risk assessment, the features of revenue taxes are advantageous. A low-margin firm produces relatively little value per unit of activity. Therefore, even small negative externalities can render a low-margin firm's operation socially harmful. In addition, the limited liability tax will be priced as the percentage of revenue for similar firms based on their collective willingness to pay for limited liability. Depending on the type of firm, the percentage will vary. It is

168. Gérard P. Cachon \& Martin A. Lariviere, Supply Chain Coordination with RevenueSharing Contracts: Strengths and Limitations, 51 MGMT. SCI. 30, 31 (2005).

169. David E. M. Sappington \& Dennis L. Weisman, Revenue Sharing in Incentive Regulation Plans, 8 InFO. ECON. \& POL'Y 229, 232-35 (1996).

170. Mitchell A. Kane, Risk and Redistribution in Open and Closed Economies, 92 VA. L. REV. 867, 867-70 (2006); J. E. Stiglitz, The Effects of Income, Wealth, and Capital Gains Taxation on Risk-Taking, 83 Q. J. ECON. 263, 263 (1969); David Weisbach, Taxation and Risk-Taking with Multiple Tax Rates, 57 NAT'L TAX J. 229, 229 (2004); see also John R. Brooks II, Taxation, Risk, and Portfolio Choice: The Treatment of Returns to Risk Under a Normative Income Tax, 66 TAX L. REV. 255, 255-57 (2012) (noting that investors adjust the risk allocation of their portfolios to reduce tax liability).

171. Boris I. Bittker, A “Comprehensive Tax Base" as a Goal of Income Tax Reform, 80 HARV. L. REV. 925, 929 (1967); Andrew Chamberlain \& Patrick Fleenor, Tax Pyramiding: The Economic Consequences of Gross Receipt Taxes, SPECIAL REP. (Tax Found., Washington, D.C.), Dec. 2006, at 8-9. 
therefore unlikely that particular kinds of firms would be disadvantaged except to the extent that they collectively believe that their activities are likely to lead to actionable externalized harm.

Several measures of size are often used in accounting and finance studies: revenue, number of employees, value of assets, or possibly firm value (e.g., enterprise value). ${ }^{172}$ An explanation of why other tax bases are less desirable follows.

2. Income or profit. The corporate income tax is often understood as a withholding tax necessitated by the impracticality of collecting from individual investors, ${ }^{173}$ but it is not tied to limited liability nor is it well calibrated to risk levels. ${ }^{174}$ There is no particular reason to believe that a firm that is more profitable, and therefore has a higher income, is more active or engaged in greater risk-taking activities than firms that are less profitable or run at a loss. Income is therefore not the appropriate tax base.

Profit is not a very good measure of firm size because very large companies can have low profits or operate at a loss. Profits or operating losses in one year do not necessarily support inferences about the risk of externalization because profits are influenced by many factors other than overall activity level and expenditures on risk-mitigating measures. ${ }^{175}$

For the purpose of the extant corporate income tax, net income or profits can be reduced substantially without changing operations by recapitalizing the company-replacing equity with debt and dividends with interest payments. For practical purposes, the two forms of capital may be close to functionally equivalent, and there are no strong reasons to believe that more highly leveraged firms are less likely to externalize losses. ${ }^{176}$ To the contrary, a firm with more secured debt may

172. Osamah M. Al-Khazali \& Taisier A. Zoubi, Empirical Testing of Different Alternative Proxy Measures for Firm Size, 21 J. APPLIEd Bus. REs. 79, 79 (2011); S. S. Shalit \& U. Sankar, The Measurement of Firm Size, 59 REV. ECON. \& STAT. 290, 294 (1977). None of these size measures typically determines corporate tax liability. Instead, corporate tax liability rises with taxable income, which roughly corresponds to corporate profit.

173. Reuven S. Avi-Yonah, Corporations, Society, and the State: A Defense of the Corporate Tax, 90 VA. L. REV. 1193, 1201 (2004); Bank, supra note 88, at 897.

174. Avi-Yonah, supra note 173, at 1206.

175. William R. Gebhardt, Charles M. C. Lee \& Bhaskaran Swaminathan, Toward an Implied Cost of Capital, 39 J. ACCT. RES. 135, 154 (2001).

176. See Jensen \& Meckling, supra note 81, at 322-23 (arguing that the presence of debt can encourage greater risk-taking by equity holders to extract value from bondholders through asset substitution); Mark Roe, Brown-Vitter Cannot Fix US Banks by Itself, FIN. TIMES (May 15, 
be more capable of externalizing losses because secured creditors have higher-priority claims on assets of the firm than tort claimants and other involuntary creditors. ${ }^{177}$ Thus, a tax tied to corporate income, as conventionally defined under the internal revenue code, would be a poor proxy for risk.

Another widely used proxy for risk is earnings variability. ${ }^{178}$ The intuition is that earnings are likely to track cash flow and that greater swings on the upside imply the potential for greater swings on the downside. ${ }^{179}$ Very large downside swings could create opportunities for risk externalization.

A traditional corporate income tax generally does not tax businesses with more volatile earnings more heavily than those with more consistent earnings because of opportunities to smooth taxable income. For example, companies can carry back or carry forward net operating losses. ${ }^{180}$ Although not all losses are usable, most are. ${ }^{181}$ With full offsets of losses, the federal government is effectively a partner in risk-taking, ${ }^{182}$ and the corporate income tax will not do much to discourage excessive risk-taking resulting from limited liability.

In contrast, a limited liability tax, structured so that firms cannot offset losses, would fall more heavily on businesses engaged in riskier activities. All else being equal, these might also be the businesses with

2013), https://www.ft.com/content/3d955954-bd51-11e2-a735-00144feab7de [https://perma.cc/ RZ7P-4RT9] ("[T]he US corporate tax system is perversely biased towards debt and against equity. It allows for tax deductions of debt interest payments while taxing shareholder profits."); $c f$. Hayne E. Leland, Agency Costs, Risk Management, and Capital Structure, 53 J. FIN. 1213, 1237 (1998) ("[A]gency costs of debt related to asset substitution are far less than the tax advantages of debt.").

177. Douglas G. Baird, Importance of Priority, 82 CORNELL L. REV. 1420, 1429-31 (1997); cf. Listokin, supra note 33, at 1067-68 (finding that secured debt is used primarily to reduce agency costs and not to redistribute value from tort claimants).

178. Gebhardt, Lee \& Swaminathan, supra note 175, at 146, 154 (noting that earnings variability is often regarded by financial practitioners "as a source of risk for firm valuation" and "is likely to capture fundamental cash flow risk.").

179. Brooks, supra note 170, at 258-59 (discussing the traditional view of variance as a proxy for risk and alternate conceptions of risk that are focused on potential losses rather than volatility).

180. Mark Campisano \& Roberta Romano, Recouping Losses: The Case for Full Loss Offsets, 76 Nw. U. L. REV. 709, 715-16 (1981); Jacob Nussim \& Avraham Tabbach, Tax-Loss Mechanisms, 81 U. CHI. L. REV. 1509, 1511-18 (2014).

181. Michael Cooper \& Matthew Knittel, Partial Loss Refundability: How Are Corporate Tax Losses Used?, 59 NAT'L TAX J. 651, 651-52 (2006).

182. Kane, supra note 170 , at $869-70$. 
the greatest risk of externalizing losses to the public fisc. ${ }^{183}$ Thus, a revenue tax without loss offsets might be preferable for a limited liability tax.

It should be noted that the extant corporate income tax is not a tax on limited liability calibrated to the risk of externalization. Limited liability for owners is currently available without corporate taxes for firms using certain structures that are typically practical only when there are few owners. ${ }^{184}$ These structures include S-Corporations, privately held LLCs, and privately held partnerships. Even before LLCs and LLPs became widely available in the 1990s, limited liability was available to equity investors with minimal corporate tax through the use of a limited partnership with a corporate general partner. Limited liability with respect to tort claimants has long been available to debtholders, regardless of the choice of entity used to organize the firm.

If an LLC or a partnership becomes publicly traded, the firm can more readily access capital from many investors, each of whom need only contribute a small fraction of his or her assets. The cost of such access to capital is that these entities are generally subject to corporate taxation. However, there are exceptions for publicly traded LLCs and partnerships engaged in certain activities. Many of these exempt activities-real estate, energy, and natural resource extraction and transportation - may be high risk. ${ }^{185}$

183. This is because greater volatility over a limited range of risk could also suggest a greater likelihood of more extreme losses.

184. The corporate income tax is imposed on C-corporations and on publicly traded partnerships and LLCs, but not on closely held S-corporations or on partnerships or LLCs that are not publicly traded. I.R.C. $\$ 7704$ (a)-(b) (2011) (stating that publicly traded LLCs and partnerships are taxed as corporations); Bank, supra note 88, at 943; Hamill, supra note 5, at 394, 397-98, 410, 413, 421 n.137, 423-24; Eric B. Sloan \& Matthew W. Lay, Beyond the Master Limited Partnership: A Comprehensive Review of Publicly Traded Partnerships, 88 TAX MAG. 229, 229-30 (2010).

185. There are numerous exceptions under I.R.C. $\$ 7704$ for publicly traded partnerships engaged in certain kinds of activities, or multitier entities including real estate investment trusts, regulated investment companies, and oil and gas and other mineral extraction activities. I.R.C. $\S$ 7704(c)-(d) (2011); Sloan \& Lay, supra note 184, at 232, 243. The latter exception may be ironic given widespread belief that extractive industries that increase greenhouse gas emissions have opportunities to externalize losses. Thomas W. Merrill \& David M. Schizer, The Shale Oil and Gas Revolution, Hydraulic Fracturing, and Water Contamination: A Regulatory Strategy, 98 MINN. L. REV. 145, 148-49 (2013). 
3. Number of employees. The number of employees of a firm is not an ideal measure of risk because some industries are more capital intensive or have higher output per employee than others. ${ }^{186}$

4. Assets. The value of a firm's assets is an unsatisfactory measure of firm size and risk because a firm can use its assets more or less intensively in ways that generate risk of externalized losses. For example, a building containing airborne asbestos will generate less harm if it is mostly vacant than if it is fully occupied. All else being equal, a high-asset firm probably has a lower chance of externalizing risk because of the availability of a larger pool of assets to satisfy claimants. ${ }^{187}$

5. Firm value. Firm value and market capitalization are also imperfect measures of size for the purpose of estimating risk. The benefits of externalizing risk to parties other than shareholders may be reflected in a firm's equity value. However, equity value is a noisy signal and could reflect many other factors such as expectations of future growth and profitability. ${ }^{188}$

\section{Signal vs. noise}

This section considers noise that could obscure our signal. What factors - other than investors' and managers' perceptions of risks that limited liability would enable them to externalize-could influence firms' elections between limited liability and higher taxes?

1. Investor wealth. One concern is heterogeneity in investor wealth levels. Legal protections that limit liability are most valuable to those who have the most assets to lose. Because these investors' assets are sufficiently large, recoveries may be high relative to collection costs. Legally created limited liability is not worth as much to those who have natural immunity by virtue of owning essentially nothing of value.

Thus, wealthier investors may value limited liability more highly. However, wealthier investors are also likely to be more risk tolerant. ${ }^{189}$

186. The number of employees might be useful in conjunction with other measures, particularly where concerns about manipulation of less transparent, self-reported measures might arise.

187. Shavell, Minimum Asset Requirements, supra note 130, at 67-68.

188. KOLLER, supra note 111, at 72-73, 77, 151-56, 185.

189. Michael S. Finke \& Sandra J. Huston, The Brighter Side of Financial Risk: Financial Risk Tolerance and Wealth, 24 J. FAM. \& ECON. IssuES 233, 252-53 (2003); Terrence A. Hallahan, 
Thus, variation among investors in risk aversion may help offset variation in the value of limited liability.

There seems to be little reason to believe that investor wealth would vary systematically among firms in different industries or engaged in different sorts of activities. ${ }^{190}$ Thus, differences in investor wealth may simply wash out. But if investor wealth does vary across groups of firms, the greater value of limited liability to investors with higher wealth levels could result in a limited liability tax operating in part as an inadvertent progressive wealth tax. On the other hand, the impact on wealthy investors could diminish over time if information generated by a limited liability tax results in new regulations and mandatory insurance regimes that erode judgment-proof investors' cost advantages.

2. Risk aversion. Corporate governance is a product of investor preferences, managerial preferences, and each group's relative degree of control. Greater risk aversion should be associated with lower risk of externalization, because risk-averse parties will fear the losses they might incur in a downside scenario more than they value actuarially equivalent gains in an upside scenario. However, risk-averse investors will also value limited liability more than risk-neutral investors and therefore be more willing to pay for it, even at a lower risk level. If investor risk aversion consistently varies across categories of firms, this could introduce noise affecting the signal created by firms' elections.

As discussed above, fully diversified investors are often assumed to be risk neutral with respect to firm-specific risks, while investors who are not diversified and have a larger share of their wealth at risk in one investment may be more risk averse. All else being equal, this may suggest that structures that facilitate diversification-like publicly tradable and widely held ownership interests - tend to increase the risk of externalized losses by making investors more risk preferring. In contrast, investors in smaller, closely held companies with a small number

Robert W. Faff \& Michael D. McKenzie, An Empirical Investigation of Personal Financial Risk Tolerance, 13 FIN. SERV. ReV. 57, 64-67 (2004); cf. Claudia R. Sahm, How Much Does Risk Tolerance Change?, 02 Q.J. FIN., no. 2, 2012, at 11 (finding that "[a] 10\% higher level of average income is associated with a $0.9 \%$ higher relative risk tolerance").

190. Cf. William N. Goetzmann \& Alok Kumar, Equity Portfolio Diversification, 12 REV. FIN. 433, 449 (2008) (finding that "older, wealthier, more experienced, and financially sophisticated investors" hold more diverse investment portfolios). See generally Ajay Khorana, Henri Servaes \& Peter Tufano, Explaining the Size of the Mutual Fund Industry Around the World, 78 J. FIN. ECON. 145 (2005) (noting that mutual funds, entities that invest in groups of firms to diversify risk, flourish in countries with wealthier and more educated populations). 
of investors, each of whom have a large portion of their wealth tied up in the business, may be more risk averse.

However, it is not necessarily the case that smaller, closely held firms are managed more conservatively than larger firms. The investors and managers of smaller firms may have sufficiently substantial assets that they can diversify even while making large, illiquid investments in individual firms. Or they may be risk-seeking. ${ }^{191}$ Among investors, those with greater income and wealth are generally assumed to be more tolerant of risk, ${ }^{192}$ and also likely to benefit more from limited liability than less wealthy investors who are more likely to be judgment proof.

In the absence of strong evidence about a relation between the type of business entity and the risk of externalized losses, the most sensible approach may be to tax equally regardless of business entity, as long as an entity confers limited liability. Thus, unlike the extant corporate income tax, a limited liability tax would also apply to LLCs, SCorporations, LLPs, and LPs.

3. Agency costs. Publicly traded companies with diversified investors might not be run in a riskier fashion than smaller, closely held companies because of greater agency costs. Managers are often assumed to be more risk averse than investors because managers cannot diversify their employment in the same way that investors can diversify their investments. ${ }^{193}$ Diffuse ownership structures likely make it more challenging for shareholders to play a large role in governance. In the absence of shareholder pressure, managers may take fewer risks than would be optimal for shareholders. ${ }^{194}$

Incentive compensation tied to share price can be used to align managerial interests more closely with those of shareholders, overcome agency costs, and increase corporate risk-taking. ${ }^{195}$ If incentive compensation aligns managerial and shareholder interests, then firms

191. Robert E. Hall \& Susan E. Woodward, The Burden of the Nondiversifiable Risk of Entrepreneurship, 100 AM. ECON. REV. 1163, 1184-85 (2010).

192. Hallahan et al., supra note 189, at 58-59.

193. John Armour \& Jeffrey N. Gordon, Systemic Harms and Shareholder Value, 6 J. LEGAL ANALYSIS 35, 36 (2014).

194. Bank, supra note 88 , at 893 (describing managerial preferences to retain earnings and lock in a stable source of capital).

195. Jensen \& Meckling, supra note 81, at 308. Such incentive compensation is explicitly encouraged under the Internal Revenue Code. For example, pay to top executives above $\$ 1$ million is only deductible with respect to corporate taxes if that pay is in the form of incentive compensation tied to stock price. I.R.C. $\$ 162(\mathrm{~m})$ (2011). 
will likely make the optimal election with respect to the limited liability tax. ${ }^{196}$ If agency costs cause firms to behave as if they were risk averse, then the optimal proportion of firms electing limited liability (i.e., the proportion that suggests limited liability is appropriately priced) will be more than half.

As noted above, investors have many tools at their disposal to both monitor managers ${ }^{197}$ and to align managers' interests with their own. These are further bolstered by fiduciary duties and personal liability for managers, particularly in the wake of In re Caremark Int'l Inc. Derivative Litigation ${ }^{198}$ and Sarbanes-Oxley. ${ }^{199}$ Shareholders could also override management's decision to forgo limited liability by opting for limited liability for their own holdings and paying their share of the fee.

Some might nevertheless worry that managers could be reluctant to elect limited liability out of concern that such an election would be perceived as a negative signal by investors (potential defendants). A study of the transition of law firms from general partnerships to limited liability partnerships suggests that such concerns about signaling may be overstated. Law firm clients (potential plaintiffs) did not perceive a shift by their law firms to limited liability to be a negative signal. ${ }^{200}$

4. Capital structure. Capital structure will be largely irrelevant to the election as long as both the limited liability tax and the alternative-unlimited pro rata liability-are insensitive to a firm's

196. Bratton \& Wachter, supra note 80 , at 726-28. Some scholars now worry that incentive compensation might lead to risk-taking that is excessive even from the perspective of risk-tolerant shareholders. See, e.g., Bebchuk, Cohen \& Spamann, supra note 86, at 273-76; Bolton, Mehran, \& Shapiro, supra note 86, at 2139-41; Zhiyong Dong, Cong Wang \& Fei Xie, Do Executive Stock Options Induce Excessive Risk Taking?, 34 J. BANKING \& FIN. 2518, 2522 (2010); Andrew Lund \& Gregg Polsky, The Diminishing Returns of Incentive Pay in Executive Compensation Contracts, 87 Notre DAME L. REV. 677, 724-25 (2011); Tung, supra note 86, at 1206-07.

Alternative compensation arrangements, such as restricted shares or defined benefit pension plans, may help make managers more cognizant of long-term risks, particularly if proportionate unlimited liability attaches to the restricted shares. Tung, supra note 86, at 1241-47.

197. See supra Part IV.A.

198. In re Caremark Int'l Inc. Derivative Litigation, 698 A.2d 959 (Del. Ch. 1996).

199. Stephen M. Bainbridge, Caremark and Enterprise Risk Management, 34 J. CORP. L. 967 , 968 (2009); H. Lowell Brown, Corporate Director's Compliance Oversight Responsibility in the Post Caremark Era, 26 DEL. J. CORP. L. 1, 4-6 (2001); Jack B. Jacobs, Fifty Years of Corporate Law Evolution: A Delaware Judge's Retrospective, 5 HARV. BUS. L. REV. 141, 150 (2015); E. Norman Veasey \& Christine T. Di Guglielmo, What Happened in Delaware Corporate Law and Governance from 1992-2004? A Retrospective on Some Key Developments, 153 U. PA. L. REV. 1399, 1436-39 (2005).

200. Scott Baker \& Kimberly D. Krawiec, The Economics of Limited Liability: An Empirical Study of New York Law Firms, 2005 U. ILL. L. REV. 107, 146-47 (2005). 
choice of capital structure. Revenue, unlike income, does not depend on capital structure. If pro rata unlimited liability is extended from shareholders to holders of warrants and financial creditors, then unlimited liability will also be insensitive to capital structure. However, if unlimited liability only applies to shareholders, then efforts to evade unlimited liability through financial engineering and changes in capital structure could present challenges. ${ }^{201}$

5. Positive externalities and innovation. Would taxing limited liability disproportionately burden firms that generate positive externalities and innovation? This seems unlikely, unless positive and negative externalities were highly correlated-in which case there might be no net externalities to worry about in the first place. The risk of externalization is not necessarily greater for more innovative firms. Even in ostensibly mature industries, new scientific knowledge related to risk is continuously discovered. ${ }^{202}$

Limited liability with respect to tort claims and government fines is most attractive to those who expect to be found liable, presumably because they are funding activities they believe are potentially dangerous to other people. There are certainly positive externalities to economic activity, but there is no reason to believe that positive externalities are correlated with either negative externalities or risk aversion.

If positive and negative externalities are uncorrelated, and the limited liability tax falls most heavily on those activities that produce more negative externalities, then the limited liability tax is likely more efficient than taxes that fall equally on activities regardless of their output of positive and negative externalities. ${ }^{203}$ This is true even if all activities have net positive externalities, as long as one assumes that the government needs a source of revenue. ${ }^{204}$ Any negative impact on economic growth or innovation from a limited liability tax could be offset with

201. See supra Part II.E.

202. See, e.g., Anderson Abel de Souza Machado et al., Microplastics as an Emerging Threat to Terrestrial Ecosystems, 24 Global Change BIOLOGY 1, 1 (2018); McLinden et al., supra note 16 , at 1 .

203. Arthur Pigou, The ECONOMics of Welfare 224-25 (2013); Baumol, supra note 13, at 307; cf. Victor Fleischer, Curb Your Enthusiasm for Pigovian Taxes, 68 VAND. L. REV. 1673, 1679 (2015).

204. There is also a safety valve if the government overprices, because private firms have the option of declining to pay for limited liability and seeking private insurance instead (at least for insurable risks up to insurable limits). 
increases in public investment or reductions in other, less efficient taxes. ${ }^{205}$

Limited liability operates in the shadow of the tort system. If the tort system undercompensates victims for reasons other than limited liability, then a limited liability fee priced according to firms' and investors' willingness to pay would likely be low relative to externalized harms and would rarely discourage socially beneficial activity. Concerns about extremely high investor risk aversion could be further addressed by setting the target percentage of firms that opt in to limited liability within a risk group relatively high.

Innovation has cachet, and it is too easy to forget many innovations that the world would probably have been better off without, such as Agent Orange, ${ }^{206}$ hydrogen-filled blimps, ${ }^{207}$ and lead additives in gasoline. ${ }^{208}$ Encouraging innovators and their funders to be mindful of risks to others is prudent.

\section{CONCLUSION}

This Article contributes to the optimal tax, corporate tax, and regulation and insurance literatures by considering limited liability as a form of public insurance that encourages greater risk-taking. In situations where businesses are already operating to maximize value for risk-neutral investors, limited liability leads to risk-taking that is socially excessive. Some specific risks that were externalized to the government or other members of the public have been identified in the past and addressed through regulation or mandatory public or private insurance programs. Nevertheless, these risks were not always known, and it stands to reason that at any given point there will be risks that have not yet been identified.

Although the precise nature and level of residual risks that might be externalized remain unknown, they are known unknowns: we know

205. See infra Appendix Part C.

206. See Facts About Herbicides, U.S. DEP'T OF VETERANS AFFAIRS, https://www.publichealth.va.gov/exposures/agentorange/basics.asp [https://perma.cc/3HMD-P2PP] (providing an overview of the history, chemical composition, and health effects of Agent Orange).

207. See Donovan Webster, What Really Felled the Hindenburg?, SMITHSONIAN MAG. (May 4, 2017), https:/www.smithsonianmag.com/smithsonian-institution/80th-anniversary-hindenburg -disaster-mysteries-remain-180963107 [https://perma.cc/3E5X-YDZV(describing the Hindenburg Disaster that happened in 1937, when a hydrogen-filled airship crashed in New Jersey).

208. See Philip J. Landrigan, Editorial, The Worldwide Problem of Lead in Petrol, 80 BULLETIN OF THE WORLD HEALTH ORGANIZATION 768 (2002) (describing the history of adding lead to gasoline and its disastrous health effects). 
that these risks exist, that they are greater than zero, and that industry participants often understand them better than regulators or the general public. Taxing limited liability can help improve efficiency both by forcing businesses to signal their degree of riskiness by opting either for limited liability or lower taxes, and by internalizing costs that would otherwise be externalized. This self-sorting would accelerate the risk discovery process by enabling those charged with managing risk to focus on self-identified high-risk firms. The key to maximizing the benefits, and minimizing the costs, of a limited liability tax is to price according to risk to the greatest extent possible.

\section{APPENDIX: ADMINISTRATIVE DETAILS}

This Appendix briefly considers specific issues relating to the administration of a limited liability tax.

\section{A. Multi-tier companies and pyramiding}

Companies and wealthy individuals routinely respond to taxation with tax avoidance strategies. Any tax regime therefore requires antievasion rules and enforcement. A likely tax avoidance strategy is to divide operations and assets between limited liability and non-limited liability entities, ${ }^{209}$ or to create multi-tiered or pyramid entities. These strategies could be policed by consolidating the revenues of non-limited liability entities with those of the limited liability entities that have invested in them. As noted above, individuals or mutual fund managers could invest in unlimited liability companies through a limited liability entity. Passive investors would simply pay the proportional equivalent of what the portfolio company would have had to pay for limited liability for the investors' interest in the company. The portfolio company would then count as partially electing limited liability, based on the fraction of investors who opt in despite management's decision to forgo limited liability.

209. The classic example is the use of a corporation as a general partner in a limited partnership. Hamill, supra note 5, at 410-12. There are many examples of the use of "blocker" and "stopper" entities. Willard B. Taylor, "Blockers," "Stoppers," and the Entity Classification Rules, 64 TAX LAWYER 1, 1 (2010); see also LoPucki, supra note 65, at 69-71 (discussing judgment-proofing strategies based around dividing operations between asset-holding and risk-taking entities). 


\section{B. Who should collect?}

A second question is who should collect the limited liability tax. Ostensibly, this should be any government entity that will absorb externalized harms. Such harms increase burdens on public insurance programs, such as those that provide health and disability benefits in the ordinary course, including Medicaid, Medicare, Social Security, and state and local equivalents. Economic damage could also erode the tax base. And externalized harms might require public bailouts if they are large enough. Externalization of losses represents a cost borne at least in part by various levels of government.

Enforcement would be easier if an unlimited liability regime were implemented at the federal rather than state level. ${ }^{210}$ Federal limited liability taxes might also be easier to administer. Federal taxes are less subject to competition and avoidance than state taxes. But state taxes would facilitate different assessments of risk levels and enable regulators to observe firm responses at different price points. Firms that disagreed vehemently enough with states' assessments of risk could refuse to do business in those states, just as firms can decline to do business in states with excessive sales or income taxes, or overly plaintiff-friendly tort systems.

\section{How should the money be spent?}

A third question is how the revenue collected should be spent. How the money is spent is largely irrelevant to the goals of reducing information asymmetries regarding externalization risk, internalizing those risks, and dynamically improving regulation, with one exception. The funding could establish an agency to gather and analyze the data about risk generated by the limited liability tax and firm elections, reprice limited liability between periods, study potentially hazardous activities more closely, and make recommendations regarding regulation and mandatory insurance.

The shorter the election periods and the more frequently limited liability is repriced, the sooner the price will be optimized based on firms' elections, and the closer the price will be to the optimal price at

210. See Grundfest, supra note 101, at 395-96 (explaining that it would be difficult for state courts to assert personal jurisdiction over out-of-state shareholder defendants in a proportionate liability regime because of constitutional requirements). Note that proportionate liability is effectively equivalent to unlimited liability because liable defendants pay their portion of the harm caused, without limitation by any other principle. 15 U.S.C. $§ 6605$ (a) (2012). 
any given time. However, the shorter the periods, the more expensive the system will be to administer. It may therefore be sensible to initially start with relatively short periods during a calibration phase - perhaps 2 years ${ }^{211}$-and then move to longer periods-perhaps close to 5 years ${ }^{212}$ - once pricing seems to stabilize near the optimal level.

In any case, such an agency (or agencies) would likely require only a fraction of the revenue a limited liability tax would raise. All money flowing into and out of government is fungible. At some point, governments will spend money dealing with risks that have been externalized. The money collected can be used to pay down public debt, reduce other taxes, or increase spending in earlier periods, as long as the government is capable of increasing taxes or borrowing in later periods.

If policymakers were concerned that a limited liability tax could decrease investment and positive externalities, ${ }^{213}$ then funds could be used to boost public investments that are complementary to innovation and economic growth, such as education, infrastructure, and R\&D spending, ${ }^{214}$ to invest directly in the private sector through a sovereign wealth fund that could also act as a rainy-day fund, ${ }^{215}$ or to reduce taxes

211. State limited liability company registrations are typically renewed biennially.

212. Term loans, which entail assessments of risk by creditors, typically last five to seven years.

213. See supra Part IV.C.5.

214. See JefFrey D. SACHS, The Price of Civilization: ReAWAKEning American VIRTUE AND PROSPERITY 18, 59, 175, 201, 220, 221, 258, 290 (revised ed. 2012) (discussing the need for increased funding for infrastructure, education, and R\&D to promote economic growth); L. Jay Helms, The Effect of State and Local Taxes on Economic Growth: A Time Series-Cross Section Approach, 67 REV. ECON. \& STAT. 574, 574 (1985) ("[W]hen [tax] revenue is used ... to finance improved public services (such as education, highways, and public health and safety) the favorable impact on location and production decisions provided by the enhanced services may more than counterbalance the disincentive effects of the associated taxes."); Michael Simkovic, The Knowledge Tax, 82 U. CHI. L. REV. 1981, 1982-2003 (2015) (discussing the links between education and economic growth, and evidence of underinvestment in higher education); International Monetary Fund, Unproductive Public Expenditures: A Pragmatic Approach to Policy Analysis, 48 IMF PAMPHLET SERIES 1, 20-26 (2005), http://www.elibrary.imf.org/view/IMF054/158319781557755414/15831-9781557755414/15831-9781557755414.xml [https://perma.cc/7QAK-H6RL] (discussing the relative contributions of education, infrastructure, health, nutrition, and military spending to economic growth).

215. See generally Bader Alhashel, Sovereign Wealth Funds: A Literature Review, 78 J. ECON. \& BUS. 1 (2015) (discussing the role of sovereign wealth funds in public saving and stabilizing government revenue, as well as controversies surrounding their returns and the extent to which they act politically rather than economically). 
that decrease economic growth and are less targeted at risk externalization. ${ }^{216}$ Establishing a rainy-day fund may be advisable if it is easy for the potential tax base to permanently leave the jurisdiction and thereby escape taxation, ${ }^{217}$ or if the government is liquidity constrained and would be unable to borrow at reasonable rates when externalized harms materialize. ${ }^{218}$

216. Simkovic, supra note 214, at 2030-34 (arguing for reductions in taxes that disproportionately burden skilled labor and investment in higher education and research); Jens Arnold, Do Tax Structures Affect Aggregate Economic Growth? Empirical Evidence from a Panel of OECD Countries 18 (OECD Econ. Dep't, Working Paper No. 643, 2008) (finding that individual and corporate income taxes have a more negative impact on economic growth than property taxes); but see Jing Xing, Tax Structure and Growth: How Robust Is the Empirical Evidence?, 117 ECON. LETTERS 379, 379-82 (2012) (disputing the evidence that tax structure affects economic growth).

217. Mitchell A. Kane \& Edward B. Rock, Corporate Taxation and International Charter Competition, 106 MICH. L. REV. 1229, 1238-41 (2008) (discussing taxation and regulatory competition); Kane, supra note 170, at 87-93 (discussing corporate arbitrage of differences in international tax rates).

218. See, e.g., Henning Bohn, The Behavior of U.S. Public Debt and Deficits, 113 Q. J. ECON. 949, 959-62 (1998) (arguing that U.S. federal borrowing capacity may have limits); James D. Hamilton \& Marjorie A. Flavin, On the Limitations of Government Borrowing: A Framework for Empirical Testing, 76 AM. ECON. REV. 808, 819 (1986) (same); cf. John H. Cochrane, A Frictionless View of U.S. Inflation, 13 NBER MACROECON. ANN. 323, 326-28 (1998) (arguing that inflation adjusts to ensure fiscal solvency). 